\title{
Reminder systems and late patient tracers in the diagnosis and management of tuberculosis (Review)
}

Liu Q, Abba K, Alejandria MM, Balanag VM, Berba RP, Lansang MAD

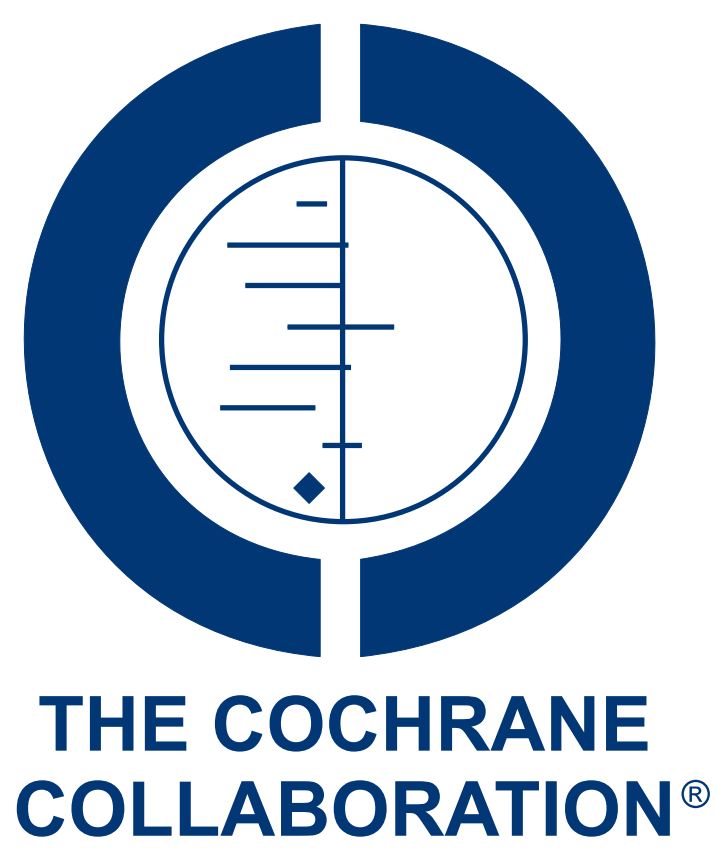

This is a reprint of a Cochrane review, prepared and maintained by The Cochrane Collaboration and published in The Cochrane Library 2008, Issue 4

http://www.thecochranelibrary.com

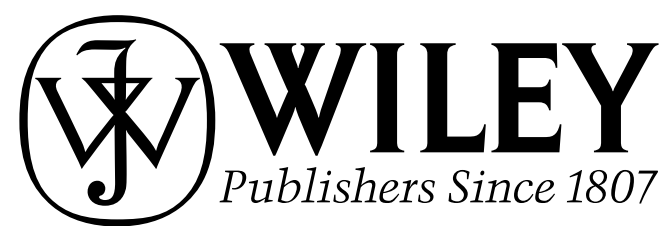

Reminder systems and late patient tracers in the diagnosis and management of tuberculosis (Review)

Copyright (C) 2008 The Cochrane Collaboration. Published by John Wiley \& Sons, Ltd. 
TABLE OF CONTENTS

HEADER . . . . . . . . . . . . . . . . . . . . . . . . . . . . . . . . . . . . . . . 1

ABSTRACT . . . . . . . . . . . . . . . . . . . . . . . . . . . . . . . . . . . . . . . . . . . . . . 1

PLAIN LANGUAGE SUMMARY . . . . . . . . . . . . . . . . . . . . . . . . . . . . . . . . . . . . . . $\quad . \quad 2$

BACKGROUND . . . . . . . . . . . . . . . . . . . . . . . . . . . . . . . . . . . . . 2

OBJECTIVES . . . . . . . . . . . . . . . . . . . . . . . . . . . . . . . . . . . . . 44

METHODS . . . . . . . . . . . . . . . . . . . . . . . . . . . . . . . . . . . . . . 44

RESULTS . . . . . . . . . . . . . . . . . . . . . . . . . . . . . . . . . . . . . . . 7

Figure 1. . . . . . . . . . . . . . . . . . . . . . . . . . . . . . . . . . . . . . 10

Figure 2. . . . . . . . . . . . . . . . . . . . . . . . . . . . . . . 11

Figure 3. . . . . . . . . . . . . . . . . . . . . . . . . . . . . . . . . . . . . . 13

Figure $4 . \quad$. . . . . . . . . . . . . . . . . . . . . . . . . . . . . . . . . . . . . 14

DISCUSSION . . . . . . . . . . . . . . . . . . . . . . . . . . . . . . . 14

AUTHORS' CONCLUSIONS . . . . . . . . . . . . . . . . . . . . . . . . . . . . . . . 15

ACKNOWLEDGEMENTS . . . . . . . . . . . . . . . . . . . . . . . . . . . . . . . . . . . . . . . . . 16

REFERENCES . . . . . . . . . . . . . . . . . . . . . . . . . . . . . . . . . . . . . 16

CHARACTERISTICS OF STUDIES . . . . . . . . . . . . . . . . . . . . . . . . . . . . . . . . . . . 18

DATA AND ANALYSES . . . . . . . . . . . . . . . . . . . . . . . . . . . . . . . . . . . . . . . . . . . . . . $\quad .27$

Analysis 1.1. Comparison 1 Late patient tracers vs no late patient tracer, Outcome 1 Patients who did not complete treatment.

Analysis 1.2. Comparison 1 Late patient tracers vs no late patient tracer, Outcome 2 Failure of patients to return to treatment after first missed appointment. . . . . . . . . . . . . . . . . . . . . . . . . .

Analysis 2.1. Comparison 2 Late patient tracers (home visit plus health education) vs usual care, Outcome 1 Patients who did not complete treatment.

Analysis 2.2. Comparison 2 Late patient tracers (home visit plus health education) vs usual care, Outcome 2 Treatment interrupted for 2 consecutive months or more.

Analysis 2.3. Comparison 2 Late patient tracers (home visit plus health education) vs usual care, Outcome 3 Treatment failure.

Analysis 2.4. Comparison 2 Late patient tracers (home visit plus health education) vs usual care, Outcome 4 Death. .

Analysis 2.5. Comparison 2 Late patient tracers (home visit plus health education) vs usual care, Outcome 5 Sputum-smear positive follow up.

Analysis 3.1. Comparison 3 Late patient tracers (home visit) vs letter, Outcome 1 Patients who did not complete treatment. . . . . . . . . . . . . . . . . . . . . . . . . . . . . . . . . . . .

Analysis 3.2. Comparison 3 Late patient tracers (home visit) vs letter, Outcome 2 Failure of patients to return for treatment after missed appointment.

Analysis 4.1. Comparison 4 Reminders (automated telephone message) vs no message, Outcome 1 Non-attendance at clinic appointment. . . . . . . . . . . . . . . . . . . . . . . . . . . . . . . . . . . . . . . . . .

Analysis 5.1. Comparison 5 Reminders (non-automated reminder phone call) vs no reminder, Outcome 1 Non-adherence to Mantoux test reading.

Analysis 6.1. Comparison 6 Reminder plus health education vs usual care, Outcome 1 Non-adherence to final clinic appointment. . . . . . . . . . . . . . . . . . . . . . . . . . . . . . . . . . .

Analysis 7.1. Comparison 7 Reminder vs other types of reminders and no reminder, Outcome 1 Failed to return for skin test reading.

Analysis 7.2. Comparison 7 Reminder vs other types of reminders and no reminder, Outcome 2 Failed to return for skin test reading. . . . . . . . . . . . . . . . . . . . . . . . . . . . . . . . . . . 36

HISTORY . . . . . . . . . . . . . . . . . . . . . . . . . . . . . . . . . . . . . . . 37

CONTRIBUTIONS OF AUTHORS . . . . . . . . . . . . . . . . . . . . . . . . . . . . . . . . . . . . . $\quad . \quad 37$

DECLARATIONS OF INTEREST . . . . . . . . . . . . . . . . . . . . . . . . . . . . . . . . . . . . . . . .

SOURCES OF SUPPORT . . . . . . . . . . . . . . . . . . . . . . . . . . . . . . . . . . . . . . . . . . 37

DIFFERENCES BETWEEN PROTOCOL AND REVIEW . . . . . . . . . . . . . . . . . . . . . . . . . . 37

INDEX TERMS . . . . . . . . . . . . . . . . . . . . . . . . . . . . . . . . . . . . . . 37

Reminder systems and late patient tracers in the diagnosis and management of tuberculosis (Review)

Copyright ( 2008 The Cochrane Collaboration. Published by John Wiley \& Sons, Ltd. 


\title{
[Intervention Review]
}

\section{Reminder systems and late patient tracers in the diagnosis and management of tuberculosis}

\author{
Qin Liu ${ }^{1}$, Katharine $\mathrm{Abba}^{2}$, Marissa M Alejandria ${ }^{3}$, Vincent M Balanag ${ }^{4}$, Regina P Berba ${ }^{5}$, Mary Ann D Lansang ${ }^{3}$ \\ ${ }^{1}$ Effective Healthcare Research Programme Consortium China (Chongqing) RPC Programme, School of Public Health, Chongqing \\ Medical University, Chongqing, China. ${ }^{2}$ International Health Group, Liverpool School of Tropical Medicine, Liverpool, UK. \\ ${ }^{3}$ Department of Clinical Epidemiology, College of Medicine, University of the Philippines, Manila, Philippines. ${ }^{4}$ Lung Center of the \\ Philippines, Quezon City, Philippines. ${ }^{5}$ Infectious Diseases Section, University of the Philippines, Manila, Philippines \\ Contact address: Qin Liu, Effective Healthcare Research Programme Consortium China (Chongqing) RPC Programme, School of \\ Public Health, Chongqing Medical University, No.1 YixueYuan Road, Chongqing, 400016, China. liuqin81622@163.com.
}

Editorial group: Cochrane Infectious Diseases Group.

Publication status and date: New, published in Issue 4, 2008.

Review content assessed as up-to-date: 17 June 2008.

Citation: Liu Q, Abba K, Alejandria MM, Balanag VM, Berba RP, Lansang MAD. Reminder systems and late patient tracers in the diagnosis and management of tuberculosis. Cochrane Database of Systematic Reviews 2008, Issue 4. Art. No.: CD006594. DOI: 10.1002/14651858.CD006594.pub2.

Copyright (C) 2008 The Cochrane Collaboration. Published by John Wiley \& Sons, Ltd.

\begin{abstract}
A B S T R A C T
Background

Reminder systems and late patient tracers as strategies to improve patients' adherence to tuberculosis screening, diagnosis, and treatment are used in some countries, but their effectiveness has not previously been systematically reviewed.
\end{abstract}

Objectives

To assess the effects of reminder systems and late patient tracers on completion of diagnostics, commencement of treatment in people referred for curative or prophylactic treatment of tuberculosis, completion of treatment in people starting curative or prophylactic treatment for tuberculosis, and cure in people being treated for active tuberculosis.

\section{Search strategy}

We searched the Cochrane Infectious Diseases Group Specialized Register (June 2008), Cochrane Effective Practice and Organization of Care Group Specialized Register (April 2007), CENTRAL (The Cochrane Library 2008, Issue 2), MEDLINE (1966 to June 2008), EMBASE (1974 to June 2008), LILACS (1982 to June 2008), CINAHL (1982 to June 2008), SCI-EXPANDED (1945 to June 2008), SSCI (1956 to June 2008), $m$ RCT (June 2008), Indian Journal of Tuberculosis (1983 to June 2008), and reference lists. We also contacted researchers working in the field.

\section{Selection criteria}

Randomized controlled trials (RCTs), including cluster RCTs and quasi-RCTs, and controlled before-and-after studies comparing any reminders or late patient tracers with no or other kinds of reminders or late patient tracers. We included people in any setting who require treatment for tuberculosis or require prophylaxis against tuberculosis and are referred to tuberculosis diagnostic or screening services.

\section{Data collection and analysis}

Two authors independently assessed trial risk of bias and extracted data. No meta-analysis could be undertaken due to the heterogeneity of interventions across trials. 


\section{Main results}

Nine trials involving 5257 participants met the inclusion criteria. Three assessed the use of late patient tracers, and six assessed reminder systems. Late patient tracers (home visit and letter) were shown to be beneficial in increasing adherence to tuberculosis treatment compared with no late patient tracer. The results from almost all the reminder trials, except one, show benefits of different types of reminders compared to no reminder on adherence to tuberculosis clinic appointments.

\section{Authors' conclusions}

The included trials show significantly better outcomes among those tuberculosis patients for which late patient tracers and reminders are used. Studies of good quality (large and with rigorous study design) are needed to decide the most effective late patient tracer actions and reminders in different settings. Future studies of reminders in chemoprophylaxis and treatment settings would be useful.

\section{PLAIN LANGUAGE SUMMARY}

\section{Reminder systems and late patient tracers in the diagnosis and management of tuberculosis}

This review aimed to assess the effects of reminder systems and late patient tracers on patients' adherence to medical advice (such as attending clinic appointments for taking anti-tuberculosis drugs) and on clinical outcomes (such as cure of tuberculosis) in the following situations: treatment for active tuberculosis; tests for diagnosis of tuberculosis; and treatment to prevent tuberculosis in high-risk individuals. Reminder systems are used before a clinic or drug-collection appointment to remind patients to attend the appointment, or sometimes during treatment at home to remind patients to take their drugs. Late patient tracers are similar interventions undertaken when patients fail to keep an appointment to encourage them to return to treatment. The review found nine trials involving 5257 participants. Six trials assessed reminder systems and three trials assessed the use of late patient tracers. The results from five of the six reminder trials showed benefits. Trials of late patient tracers (home visits and letters) also showed benefits of the intervention in increasing adherence to tuberculosis treatment. Hence, overall, the results showed better outcomes among those patients for whom reminders or late patient tracers were used.

\section{B A C K G R O U N D}

\section{Prevalence of tuberculosis}

Tuberculosis is a growing international health concern. As a cause of human suffering, death, and impoverishment, tuberculosis ranks among the leading infectious diseases. About two billion people, or nearly one-third of the world's population, are thought to be infected with Mycobacterium tuberculosis. There were almost 8.8 million new cases of active tuberculosis in 2005, and there are an estimated 1.6 million deaths from tuberculosis each year ( WHO 2007).

\section{Diagnosis and treatment}

Methods of tuberculosis diagnosis vary depending on the infection, site, patient age, availability of facilities, and local policy. The standard method of diagnosis for active pulmonary tuberculosis is sputum microscopy, where people provide two or three sputum samples, including an early morning sample, collected on separate occasions. Sputum culture is also used; this detects more cases but takes longer for the results to become available. Patients are advised to return to the clinic to receive the results, while those with positive results are usually referred for treatment. Those with negative sputum smear results may undergo further investigation for tuberculosis, may need to return for the results of sputum culture tests, or both.

In some countries, groups considered to be at high risk may be screened for tuberculosis infection (active or latent) using Purified Protein Derivative (PPD) tests (also known as tuberculin skin test), such as Mantoux or Heaf tests, or the more recently devel- 
oped interferon-gamma blood tests. PPD tests involve injecting a protein derivative of the $M$. tuberculosis bacillus into the skin, waiting 48 to 72 hours, and then measuring any localized swelling (or induration) of the skin around the injection site. People with positive results may then undergo further tests to detect or exclude active tuberculosis, followed by treatment for active cases and prophylaxis for latent infection. In this review, we consider 'prophylaxis' to mean drug prophylaxis. Prophylaxis in this case refers to measures to prevent progression from infection to disease through the administration of antituberculous drugs.

To be successful, the processes of screening, diagnosis, and treatment require all patients to attend several healthcare appointments (or contacts with healthcare staff). Unless direct observation of therapy is used, treatment for active or latent tuberculosis also requires patients to take regular self-administered medication. To cure tuberculosis with the standard regimen, the World Health Organization (WHO) recommends that at least $75 \%$ of the prescribed drugs must be taken, and, if treatment is interrupted, it must be interrupted for less than two months (WHO 2003a).

\section{Adherence}

Adherence is defined as the extent to which a person's behaviour corresponds with agreed recommendations from a healthcare provider (WHO 2003b). In the case of tuberculosis, this may be defined as the extent to which the patient's history of therapeutic drug-taking coincides with prescribed treatment. This may be using outcome-oriented definitions such as cure rate, or processrelated definitions such as appointment-keeping or pill counts ( WHO 2003b). More recently the term 'concordance' has come into use; this refers to a consensual agreement about treatment, established between patient and practitioner. In the context of this review, the two terms are interchangeable, as patients' attendance at appointments relates to both concepts (Haynes 2008).

Poor adherence to antituberculous treatment may lead to treatment failure and relapse (Ormerod 1991), drug resistance (Weis 1994; Mitchison 1998), and prolonged and expensive therapy that is less likely to be successful than the treatment of drug-susceptible tuberculosis (Goble 1993). Poor adherence also results in increased transmission rates of the tubercle bacilli, morbidity, and cost to the tuberculosis control programmes (Johansson 1999).

The WHO estimates that $60 \%$ of sputum smear-positive tuberculosis cases were detected globally in 2005 (WHO 2007), 10\% below the $70 \%$ target. It is not known how many patients are lost to follow up during the process of conducting various laboratory tests (eg sputum acid-fast bacilli smears taken two to three times) to confirm the tuberculosis diagnosis.

Globally, treatment success rates for tuberculosis since 1998 have been close to, but persistently below, the $85 \%$ target set by the WHO (WHO 2006). This gap is due not only to the high rates of death among people living with HIV/AIDS but also to high rates of treatment interruption and transfer. Also, several regions of the world are experiencing unprecedented increases in the prevalence of multiple-drug-resistant (MDR) tuberculosis, which threatens tuberculosis control and translates into low cure rates. The WHO reports that the estimated incidence in 2006 was 489,139 globally, with the proportion of MDR tuberculosis at $4.8 \%$ (95\% CI 4.6 to 6.0) (WHO 2008). There is also the severe threat of extensively drug-resistant (XDR) tuberculosis, which has an extremely high mortality rate.

Adherence to a tuberculosis treatment programme requires accessible and appropriate health care, and a number of interventions have been used to promote adherence (WHO 2003b). This Cochrane Review is one of several planned or in progress to evaluate each type of intervention:

- Reminder systems and late patient tracers in the diagnosis and management of tuberculosis: routinely reminding patients to keep an appointment and actions taken when patients fail to keep an appointment (this review).

- Staff motivation and supervision: training and management processes that aim to improve how providers care for people with tuberculosis.

- Education and counselling for promoting adherence to the treatment of active tuberculosis: provision of information or oneto-one or group counselling about tuberculosis and the need to attend for treatment (M'Imunya 2007).

- Incentives and reimbursements: money or cash in kind to reimburse expenses of attending services, or to improve the attractiveness of visiting the service.

- Contracts: written or verbal agreements to return for an appointment or course of treatment (Bosch Capblanch 2007).

- Peer assistance: people from the same social group helping someone with tuberculosis return to the health service by prompting or accompanying them.

- Directly observed therapy (DOT): an appointed agent (health worker, community volunteer, family member) directly monitors people swallowing their antituberculous drugs ( Volmink 2007).

It has long been accepted that the best way to improve adherence to long-term treatment regimens is extended supervision of and contact with patients (Haynes 2008). This review assesses the effectiveness in improving adherence with respect to two types of interventions to maintain contact with patients using diagnostic and treatment services.

\section{Reminder systems and late patient tracers}

In this review, a reminder is defined as any action to contact patients shortly before they are due to take their medication or attend a healthcare appointment for tuberculosis diagnosis or treatment, and to remind them to take their medication or attend their appointment, to ensure adherence. Late patient tracers (sometimes called 'defaulter actions') are undertaken when patients fail to keep 
an appointment, generally to attempt to make contact with the patient, sometimes to find out why they did not attend, and to help patients understand the need to attend treatment and overcome barriers to attending for treatment. The type of reminders and late patient tracers could be visits made to patients or contacts by health workers, letters, telephone calls (Thilakavathi 1993), and more recently, e-mails and SMS text messages (Green 2003). Reminders and late patient tracers may be undertaken by health service staff, volunteers, or community members. They might often include a health education component, explaining to the patient why they need to attend appointments and take their medication. Reminders and late patient tracers are not newly developed interventions, and some national treatment programmes use one or both as standard procedure. For example, in 1988 to 1989, the National Treatment Program Manuals in India recommended late patient tracers to contact patients who did not return to the clinic for their fortnightly drug collection, on the first day after a missed appointment and then on the fourth day (Jagota 1996). In Malaysia, where DOT is used, when patients have missed more than seven consecutive days of treatment, a specialist late patient tracing team visits their home to find out why they have not attended the clinic for treatment. Another visit is made if the patient subsequently fails to attend (O'Boyle 2002). Reminder systems and late patient tracers as strategies to improve patients' adherence to tuberculosis screening, diagnosis, and treatment have not been reviewed systematically before. This review seeks to fill the gap in evidence, and highlight where more research might be needed.

\section{O B JE C T I VES}

To assess the effects of reminder systems and late patient tracers on completion of diagnostics, commencement of treatment in people referred for curative or prophylactic treatment of tuberculosis, completion of treatment in people starting curative or prophylactic treatment for tuberculosis, and cure in people being treated for active tuberculosis.

\section{METHODS}

\section{Criteria for considering studies for this review}

\section{Types of studies}

- Randomized controlled trials (RCTs) including cluster RCTs and quasi-RCTs.

- Controlled before-and-after studies (CBAs).

\section{Types of participants}

- Children and adults in any setting who require treatment for tuberculosis. This includes people with pulmonary tuberculosis (diagnosed by sputum microscopy, culture, or both, regardless of HIV status), smear-negative pulmonary tuberculosis (diagnosed by symptoms and chest radiograph findings or other diagnostic tests, regardless of HIV status), or extrapulmonary tuberculosis (diagnosed by signs or symptoms and histopathology, sputum acid-fast bacilli smear, culture, or both, imaging studies or polymerase chain reaction (PCR)).

- Children and adults in any setting with tuberculosis infection who require prophylaxis against tuberculosis.

- Children and adults in any setting referred (including selfreferred) to tuberculosis diagnostic or screening services.

\section{Types of interventions}

\section{Interventions}

- Any actions taken to remind patients to take their tuberculosis medication or attend appointments (reminders) .

- Any actions to contact patients who have missed an appointment (late patient tracers).

\section{Controls}

- No reminders or late patient tracers.

- Other kinds of reminder actions or other interventions to improve adherence.

- Other kinds of late patient tracers or other interventions to improve adherence.

\section{Types of outcome measures}

\section{Primary}

- Completion of tuberculosis diagnostics.

- Completion of screening process.

- Commencement of prophylactic treatment.

- Commencement of curative treatment.

- Completion of prophylactic treatment.

- Completion of curative treatment.

- Cure.

- Incidence of active tuberculosis (in studies of prophylactic treatment). 


\section{Secondary}

- Any measure of adherence to treatment or attendance at appointments.

- Any measure of patient involvement or patient satisfaction.

- Any adverse event (eg elevated liver enzymes, optic neuritis).

\section{Search methods for identification of studies}

We attempted to identify all relevant studies regardless of language or publication status (published, unpublished, in press, and in progress).

\section{Databases}

We searched the following databases using the search terms and strategy described in Table 1: Cochrane Infectious Diseases Group Specialized Register (June 2008); Cochrane Effective Practice and Organization of Care Group Specialized Register (April 2007); Cochrane Central Register of Controlled Trials (CENTRAL), published in The Cochrane Library (2008, Issue 2); MEDLINE (1966 to June 2008); EMBASE (1974 to June 2008); LILACS (1982 to June 2008); CINAHL (1982 to June 2008); Science Citation Index Expanded (SCI-EXPANDED; 1945 to June 2008); and the Social Sciences Citation Index (SSCI; 1956 to June 2008). We also searched the metaRegister of Controlled Trials ( $m$ RCT) using the terms: 'tuberculosis' and '(reminder OR compliance)' (June 2008).

Table 1. Detailed search strategies

\begin{tabular}{|c|c|c|c|c|c|c|c|}
\hline Search set & Cochrane $\mathrm{SR}^{a}$ & CENTRAL & MEDLINE $^{b}$ & EMBASE $^{b}$ & LILACS $^{b}$ & $\begin{array}{l}\text { SCI-EX- } \\
\text { PANDED \& } \\
\text { SSCI }\end{array}$ & CINAHL \\
\hline 1 & tuberculosis & tuberculosis & tuberculosis & tuberculosis & tuberculosis & tuberculosis & tuberculosis \\
\hline 2 & adherence & $\begin{array}{l}\text { PATIENT } \\
\text { COMPLI- } \\
\text { ANCE }\end{array}$ & $\begin{array}{l}\text { TUBERCU- } \\
\text { LOSIS/ } \\
\text { DRUG } \\
\text { THERAPY/ } \\
\text { PREVEN- } \\
\text { TION AND } \\
\text { CONTROL }\end{array}$ & $\begin{array}{l}\text { TUBERCU- } \\
\text { LOSIS }\end{array}$ & adherence & adherence & adherence \\
\hline 3 & compliance & $\begin{array}{l}\text { PATIENT } \\
\text { DROPOUTS }\end{array}$ & $\begin{array}{l}\text { PATIENT } \\
\text { COMPLI- } \\
\text { ANCE }\end{array}$ & $\begin{array}{l}\text { PATIENT- } \\
\text { COMPLI- } \\
\text { ANCE }\end{array}$ & compliance & compliance & compliance \\
\hline 4 & monitor* & $\begin{array}{l}\text { REMINDER } \\
\text { SYSTEMS }\end{array}$ & $\begin{array}{l}\text { PATIENT } \\
\text { DROPOUTS }\end{array}$ & $\begin{array}{l}\text { medication ad- } \\
\text { herence }\end{array}$ & monitor* & monitor* & monitor* \\
\hline
\end{tabular}


Table 1. Detailed search strategies (Continued)

\begin{tabular}{|c|c|c|c|c|c|c|c|}
\hline 5 & reminder* & $\begin{array}{l}\text { TREAT- } \\
\text { MENT } \\
\text { REFUSAL }\end{array}$ & $\begin{array}{l}\text { COOP- } \\
\text { ERATIVE BE- } \\
\text { HAVIOUR }\end{array}$ & $\begin{array}{l}\text { REMINDER- } \\
\text { SYSTEM }\end{array}$ & reminder* & reminder* & reminder* \\
\hline 6 & $\begin{array}{l}2 \text { or } 3 \text { or } 4 \text { or } 5 \\
\text { or } 6\end{array}$ & $\begin{array}{l}\text { DIRECTLY } \\
\text { OBSERVED } \\
\text { THERAPY }\end{array}$ & $\begin{array}{l}\text { TREAT- } \\
\text { MENT } \\
\text { REFUSAL }\end{array}$ & $\begin{array}{l}\text { TREAT- } \\
\text { MENT- } \\
\text { REFUSAL }\end{array}$ & 2 or 3 or 4 or 5 & non-adherence & non-adherence \\
\hline 7 & 1 and 6 & $\begin{array}{l}\text { medication ad- } \\
\text { herence }\end{array}$ & $\begin{array}{l}\text { medication ad- } \\
\text { herence }\end{array}$ & $\begin{array}{l}\text { DIRECTLY- } \\
\text { OBSERVED- } \\
\text { THERAPY }\end{array}$ & 1 and 6 & $\begin{array}{l}\text { late patient } \\
\text { tracer }\end{array}$ & $\begin{array}{l}\text { late patient } \\
\text { tracer }\end{array}$ \\
\hline 8 & - & $\begin{array}{l}\text { electronic } \\
\text { monitoring }\end{array}$ & $\begin{array}{l}\text { REMINDER } \\
\text { SYSTEMS }\end{array}$ & $\begin{array}{l}\text { electronic } \\
\text { monitoring }\end{array}$ & - & $2-7 /$ or & $2-7 /$ or \\
\hline 9 & - & nonadherence & $\begin{array}{l}\text { electronic } \\
\text { monitoring }\end{array}$ & nonadherence & - & 1 and 8 & 1 and 8 \\
\hline 10 & - & non-adherence & nonadherence & non-adherence & - & - & - \\
\hline 11 & - & $\begin{array}{l}\text { late patient } \\
\text { tracer }\end{array}$ & non-adherence & $\begin{array}{l}\text { late patient } \\
\text { tracer }\end{array}$ & - & - & - \\
\hline 12 & - & $2-11 /$ or & $\begin{array}{l}\text { DIRECTLY } \\
\text { OBSERVED } \\
\text { THERAPY }\end{array}$ & 1 or 2 & - & - & - \\
\hline 13 & - & 1 and 12 & $\begin{array}{l}\text { late patient } \\
\text { tracer }\end{array}$ & $3-11 /$ or & - & - & - \\
\hline 14 & - & - & 1 or 2 & 13 and 14 & - & - & - \\
\hline 15 & - & - & $3-13 /$ or & - & - & - & - \\
\hline 16 & - & - & 14 and 15 & - & - & - & - \\
\hline
\end{tabular}

${ }^{a}$ Cochrane Infectious Diseases Group Specialized Register and the Cochrane Effective Practice and Organisation of Care Group Specialized Register.

${ }^{b}$ Search terms used in combination with the search strategy for retrieving trials developed by The Cochrane Collaboration (Lefebvre 2006); upper case: MeSH or EMTREE heading; lower case: free text term. 


\section{Researchers and organizations}

For unpublished and ongoing trials, we contacted study authors and other researchers working in the field and the following organizations: World Health Organization (WHO); the Tuberculosis Trials Consortium (TBTC); the International Union against TB and Lung Diseases (IUATLD); the European Developing Countries Clinical Trials Programme (EDCTP); and the Global Partnership to Stop TB.

\section{Non-indexed journals}

We searched the online Indian Journal of Tuberculosis from 1983 to June 2008 using 'tuberculosis' and '(reminder OR compliance)' as search terms.

\section{Reference lists}

We also checked the reference lists of all studies identified by the above methods.

\section{Data collection and analysis}

\section{Selection of studies}

K Abba and MA Lansang independently applied the inclusion criteria to all identified trials, and screened all citations and abstracts identified by the search strategy to exclude trials that clearly did not meet the inclusion criteria. If either of them judged that the trial might be eligible for inclusion, we obtained the full paper. After obtaining full reports of all potentially eligible studies, K Abba and $\mathrm{V}$ Balanag assessed these for inclusion in the review using a pre-designed eligibility form based on the inclusion criteria and resolved any disagreements by discussion with a third author (Q Liu). We also scrutinized publications to ensure that each trial was included only once.

\section{Data extraction and management}

Two authors from each team (M Alejandria and R Berba for reminders, Q Liu and V Balanag for late patient tracers) independently extracted the data using a tailored data extraction form. We extracted data on study design, methods, participant characteristics, interventions, and outcomes. For dichotomous data, we extracted the number of events of interest, the total number randomized to each group, and the total number analysed. For continuous data, we extracted the number of participants randomized, the number analysed, and the number of participants in each group; and also the arithmetic means and their standard deviations for some variables. Study authors were contacted to supply missing information and to clarify issues. We resolved discrepancies by discussion.

\section{Assessment of risk of bias in included studies}

Papers selected for inclusion were divided between two teams of review authors according to the type of intervention assessed (re- minders or patient tracing). Two authors in each team independently assessed the risk of bias of the included trials. M Alejandria and R Berba for reminders; and Q Liu and V Balanag for patient tracing.

For RCTs and quasi-RCTs, we assessed the generation of the allocation sequence and allocation concealment as adequate, inadequate, or unclear according to Jüni 2001. We reported who was blinded in each trial and classified blinding as yes, no, not possible, and unclear for providers, participants, and assessors, respectively. We assessed the inclusion of randomized participants in the analysis as adequate if $80 \%$ or more, unclear if not described, and inadequate if less than $80 \%$. We also assessed protection against contamination as 'done' if allocation was by community, institution, or practice and it was unlikely that the control group received the intervention, 'unclear' if providers were allocated within a clinic or practice and communication between experimental and group providers was likely to occur, and 'not done' if it was likely that the control group received the intervention.

We used a pro-forma to guide the assessment of risk of bias. We also contacted the study authors when essential information to judge quality was missing. Any disagreements were resolved by discussion and by consulting a third author (MA Lansang for reminders and V Balanag for late patient tracers) when necessary.

\section{Data synthesis}

Q Liu undertook the analysis using Review Manager 5 in consultation with the other authors. We did not pool results statistically because of heterogeneity across the type of interventions, study design, settings, and outcomes. We stratified the analysis by the indication for the intervention (screening, prophylaxis, and treatment), type of reminder or late patient tracer, and study design. Risk ratios (RR) and 95\% confidence intervals (CI) were used for dichotomous data with an available-case analysis. We will use the methods outlined in the protocol to handle other types of data (eg continuous data or analysis of cluster trials or controlled beforeand-after studies) in future updates.

We tested for heterogeneity using the $\mathrm{Chi}^{2}$ test for heterogeneity with a cut-off of $\mathrm{P}<0.10$ and the $\mathrm{I}^{2}$ test, with $>50 \%$ indicating significant heterogeneity. We did not combine trials even by the random-effects model because of the significant heterogeneity. The results were presented as forest plots without subtotals and risk ratio calculations. We will use the methods outlined in the protocol for subgroup and sensitivity analyses in future updates.

\section{R E S U L T S}

\section{Description of studies}

See: Characteristics of included studies; Characteristics of excluded studies. 
Nine studies involving 5257 participants met the inclusion criteria (see 'Characteristics of included studies'). Seven were RCTs and two were quasi-RCTs. Two were reported in one article (Roberts 1983i; Roberts 1983ii). Twelve studies that initially seemed to fit the inclusion criteria were eventually excluded for the reasons given in the 'Characteristics of excluded studies'.

\section{Type of intervention}

\section{Late patient tracers}

Three individually RCTs were included (Krishnaswami 1981; Paramasivan 1993; Mohan 2003). Krishnaswami 1981 compared the effectiveness of two kinds of late patient tracers, a home visit and if necessary up to another three visits compared with a reminder letter the first time and if necessary a home visit once. Paramasivan 1993 and Mohan 2003 compared reminder letters or routine home visiting for patients missing an appointment with a control group without late patient tracers.

\section{Reminder systems}

Two individually quasi-RCTs (Tanke 1994; Cheng 1997) and four individually RCTs were included (Roberts 1983i; Roberts 1983ii; Sanmarti 1993; Tanke 1997)

Two of the trials were carried out at the same time and location, and reported in the same article (Roberts 1983i; Roberts 1983ii), but they were separate experiments with different participants and interventions. Roberts $1983 \mathrm{i}$ compared eight groups receiving four types of return reminders, including postcard, telephone call, direct person-to-person, and take-home card in combination with two types of authority sources (experts and non-experts). Roberts 1983ii compared 12 groups receiving a combination of two types of message on the importance of returning (enhanced versus standard), two types of reminders (take-home card versus no reminder card), and three types of overt commitment to return (verbal, verbal plus written agreement, or no commitment).

Except for Tanke 1997, which compared a pre-recorded telephone reminder message (TeleMinder system) twice with no reminder message, the trials all had more than one intervention arm. Cheng 1997 applied five types of intervention for following up the tuberculosis test reading, of which the intervention of interest for this review was the reminder phone call in group 2. Tanke 1994 compared no message with four types of automated telephone reminders (basic reminder, basic reminder plus authority endorsement, basic reminder plus importance statement, and basic reminder plus importance statement plus authority endorsement) for patients scheduled for three different clinic appointments. Sanmarti 1993 compared three types of intervention with a control; the interventions in groups one and two (telephone call reminder and home visit by specialized nursing personnel) met our inclusion criteria.

\section{Countries}

Of the trials assessing late patient tracers, two were carried out in India (Krishnaswami 1981; Paramasivan 1993) and one in Iraq ( Mohan 2003). Most of the trials assessing reminders were carried out in the USA (Roberts 1983i; Roberts 1983ii; Tanke 1994; Cheng 1997; Tanke 1997), except one trial carried out in Spain ( Sanmarti 1993).

\section{Participants}

All three trials of late patient tracers were conducted among patients undergoing treatment for active tuberculosis. Krishnaswami 1981 included patients aged 12 years or more with radiographic evidence of tuberculosis but negative smears, Paramasivan 1993 studied newly diagnosed adult sputum smear-positive pulmonary tuberculosis patients, while Mohan 2003 studied new smear-positive PTB patients.

For reminders, four trials assessed the effectiveness of different reminders on the tuberculin skin test return of different groups of people (Roberts 1983i; Roberts 1983ii; Cheng 1997; Tanke 1997). Cheng 1997 studied children aged 1 to 12 years; Tanke 1997 studied persons of different ages $(<5$ years, 5 to 12 years, 13 to 19 years, 20 to 29 years, and $>29$ years); and Roberts 1983i/ Roberts 1983ii studied college students who were volunteers in a university-sponsored tuberculosis detection drive. One of the included trials was conducted in primary school children undergoing tuberculosis chemoprophylaxis (Sanmarti 1993), and the remaining trial was done in a wide range of age groups receiving tuberculosis diagnosis, tuberculosis chemoprophylaxis, or treatment (Tanke 1994).

\section{Setting}

All three late patient tracer trials were performed in clinics ( Krishnaswami 1981; Paramasivan 1993; Mohan 2003). The six reminder trials were performed in different settings, including a children's national medical centre (Cheng 1997), clinics (Tanke 1994; Tanke 1997), a primary school (Sanmarti 1993), and a university (Roberts 1983i; Roberts 1983ii).

\section{Outcomes}

Based on the outcomes defined in the protocol, the main outcome assessed in the late patient tracer trials was the number of patients who did not complete treatment. For reminders, the number of patients who did not adhere to a scheduled appointment was the main outcome assessed in the included trials.

\section{Risk of bias in included studies}

Our assessment of risk of bias is summarized in Table 2 with individual trial details provided in the 'Characteristics of included studies'. 
Table 2. Risk of bias assessment

\begin{tabular}{|c|c|c|c|c|c|c|c|}
\hline Intervention & Trial & Design & $\begin{array}{l}\text { Generation of } \\
\text { allocation se- } \\
\text { quence }\end{array}$ & $\begin{array}{l}\text { Allocation } \\
\text { concealment }\end{array}$ & $\begin{array}{l}\text { Blinded } \\
\text { assessment }\end{array}$ & $\begin{array}{l}\text { Inclu- } \\
\text { sion of ran- } \\
\text { domized par- } \\
\text { ticipants in } \\
\text { the analysis }\end{array}$ & $\begin{array}{l}\text { Protection } \\
\text { against con- } \\
\text { tamination }\end{array}$ \\
\hline \multirow[t]{3}{*}{$\begin{array}{l}\text { Late patient } \\
\text { tracers }\end{array}$} & $\begin{array}{l}\text { Krishnaswami } \\
1981\end{array}$ & RCT & Unclear & Unclear & Unclear & Adequate & Unclear \\
\hline & $\begin{array}{l}\text { Paramasivan } \\
1993\end{array}$ & RCT & Adequate & Adequate & No & Adequate & Done \\
\hline & Mohan 2003 & RCT & Adequate & Adequate & Yes & Adequate & Done \\
\hline \multirow{6}{*}{$\begin{array}{l}\text { Reminder sys- } \\
\text { tems }\end{array}$} & Roberts $1983 \mathrm{i}$ & RCT & Unclear & Unclear & Unclear & Adequate & Unclear \\
\hline & $\begin{array}{l}\text { Roberts } \\
1983 \mathrm{ii}\end{array}$ & RCT & Unclear & Unclear & Unclear & Adequate & Unclear \\
\hline & $\begin{array}{l}\text { Sanmarti } \\
1993\end{array}$ & RCT & Unclear & Unclear & Unclear & Adequate & Unclear \\
\hline & Tanke 1994 & Quasi-RCT & Inadequate & Unclear & Unclear & Adequate & Unclear \\
\hline & Cheng 1997 & Quasi-RCT & Inadequate & Unclear & Unclear & Adequate & Unclear \\
\hline & Tanke 1997 & RCT & Unclear & Unclear & Unclear & Adequate & Unclear \\
\hline
\end{tabular}

RCT: randomized controlled trial.

\section{Late patient tracers}

All three trials of late patient tracers used a RCT study design. In both Paramasivan 1993 and Mohan 2003, the generation of the allocation sequence and allocation concealment were adequate, and protection against contamination was also present; while in Krishnaswami 1981, allocation generation, allocation concealment, and protection against contamination were not clearly documented.

In all three trials, inclusion of randomized participants in the analysis was assessed as adequate, that is, over $80 \%$ of participants who were randomized in groups were included in the analysis.
Only Mohan 2003 clearly documented blinded assessment of the primary outcomes. Paramasivan 1993 did not blind outcome assessors and Krishnaswami 1981 did not explicitly state this.

\section{Reminders}

Two trials used a quasi-RCT design (Tanke 1994; Cheng 1997), and the remaining four trials used a RCT study design (Roberts 1983i; Roberts 1983ii; Sanmarti 1993; Tanke 1997). Cheng 1997 allocated by day of the week; for Tanke 1994, within each fiveweek period each message variation was used once on each weekday and different variations were used each day of a given week by 
a computer-generated system. The allocation generation in four RCTs was not clearly documented. Of all the included studies on reminders, concealment of allocation and protection against contamination were not clearly documented, while the inclusion of randomized participants in the analysis was adequate. None of the trials clearly documented blinded assessment of the primary outcomes.

\section{Effects of interventions}

\section{Late patient tracers}

Three trials assessed the use of late patient tracers, and each compared different types (eg letters or home visits). One trial also included health education with the late patient tracers.

\section{I.I. Letter versus no late patient tracer}

Paramasivan 1993 compared posting of letters reminding patients who did not collect their medication within three days of the due date to attend and collect their medication with no late patient tracers. Sixty pulmonary tuberculosis patients out of the 200 enrolled were late patients in this study. Fewer patients in the intervention group (12\%) did not complete treatment compared with the control group (27\%) (RR 0.44, 95\% CI 0.24 to $0.83 ; 200$ participants, Figure 1, Analysis 1.1). Eleven out of 23 patients in the intervention group who missed their first appointment failed to return to treatment, compared with 26 out of 29 in the control group (RR 0.53, 95\% CI 0.34 to $0.83 ; 52$ participants, Analysis 1.2). This trial also found that treatment default, which was defined by the trial as failing to collect the drugs within three days after the due date of drug collection, was high among illiterate patients but retrieval rate among them was also high in the intervention group.

Figure I. Late patient tracers vs no late patient tracer: Patients who did not complete treatment

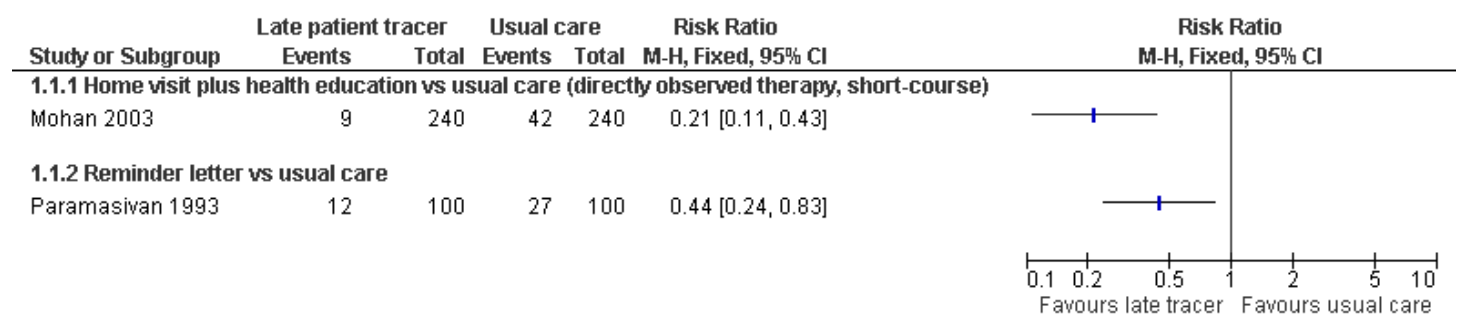




\section{I.2. Home visit plus health education versus no late patient}

tracer

Mohan 2003 studied 480 new smear-positive pulmonary tuberculosis (PTB) patients who delayed coming to collect drugs at the health centre for at least three days after a scheduled appointment. The trial compared the effectiveness of a home visit with no home visit. The home visitors also carried out health education for the patient and his/her family. Fewer participants (3.8\%) who received the home visit and health education failed to return for treatment than those who did not have a home visit (17.5\%) (RR 0.21, 95\% CI 0.11 to 0.43 ; 480 participants, Analysis 2.1 ). Fewer patients in the intervention group interrupted treatment for two consecutive months or more (RR $0.08,95 \%$ CI 0.02 to 0.35 ; 480 participants, Analysis 2.2), and there were fewer treatment failures in the home visit group (RR $0.36,95 \%$ CI 0.13 to 0.98 ; 480 participants, Analysis 2.3). The number of deaths was not significantly different between the two groups (480 participants, Analysis 2.4). Fewer patients in the intervention group were smear positive at two months' follow up (RR $0.45,95 \%$ CI 0.32 to $0.64 ; 480$ participants, Analysis 2.5), five months (RR $0.35,95 \%$ CI 0.23 to 0.54; 480 participants, Analysis 2.5), and at the end of treatment (RR $0.28,95 \%$ CI 0.17 to 0.47 ; 480 participants, Analysis 2.5 ).

\section{I.3. Home visit versus letter}

In Krishnaswami 1981, patients who failed to collect their drugs on the due date received either a home visit and, if necessary, another three visits, or a reminder letter the first time and, if necessary, one home visit. In total, 170 patients were admitted to the study, 150 of which were included in the main analysis; of these 121 were late patients. There was no significant difference between patients who received home visits and those who received reminder letters in the number of patients who did not complete treatment ( 150 participants, 1 trial, Figure 2, Analysis 3.1) or retrievals after the first action for first episode of default (121 participants, 1 trial, Analysis 3.2). However, the mean number of drug collections for one year was reported as significantly higher in the home visit group than in the reminder letter group $(9.8$ versus $8.6, \mathrm{P}=0.03)$. We were not able to calculate the mean difference and confidence interval as standard deviations were not provided.

Figure 2. Late patient tracers (home visit) vs letter: Patients who did not complete treatment

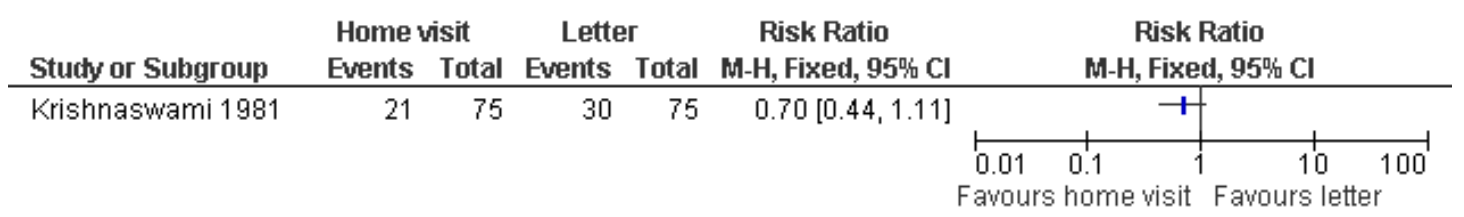


Two participants withdrew from the study because of adverse effects of the medication used (thioacetazone). Both patients were in the group receiving the less intensive follow up (letter plus one home visit if necessary) upon missed appointments.

\section{Reminders}

\section{I. Automated telephone reminders versus no reminder}

Tanke 1997 evaluated the effectiveness of automated telephone reminders on tuberculin skin test return in both children and adults. The trial authors did not present the data that would enable us to calculate risk ratios and confidence intervals (requested data from trial authors and awaiting reply). However, they reported a significantly positive effect of automated telephone reminders ( $7 \%$ failed to return) on return for skin test reading compared to no reminder message (12\% failed to return), with an odds ratio of $1.71(\mathrm{P}<0.05)$.

Tanke 1994 compared four different automated telephone reminders in patients attending three different tuberculosis clinics with no reminders. Patients in this study were scheduled for appointments at clinics for diagnosis, prophylaxis, and treatment. Those receiving reminders were significantly more likely than those not receiving reminders to attend their appointments in prophylaxis clinics (RR $0.72,95 \%$ CI 0.58 to $0.89 ; 536$ participants, Figure 3, Analysis 4.1) and treatment clinics (RR 0.69, 95\% CI 0.56 to $0.86 ; 597$ participants, Analysis 4.1), but there was no significant difference between the groups in diagnosis clinics (RR $0.94,95 \%$ CI 0.79 to $1.12 ; 857$ participants, Analysis 4.1). There were no significant differences in the effects of different kinds of messages (Analysis 4.1). 
Figure 3. Reminders (automated telephone message) vs no message: Non-attendance at clinic appointment

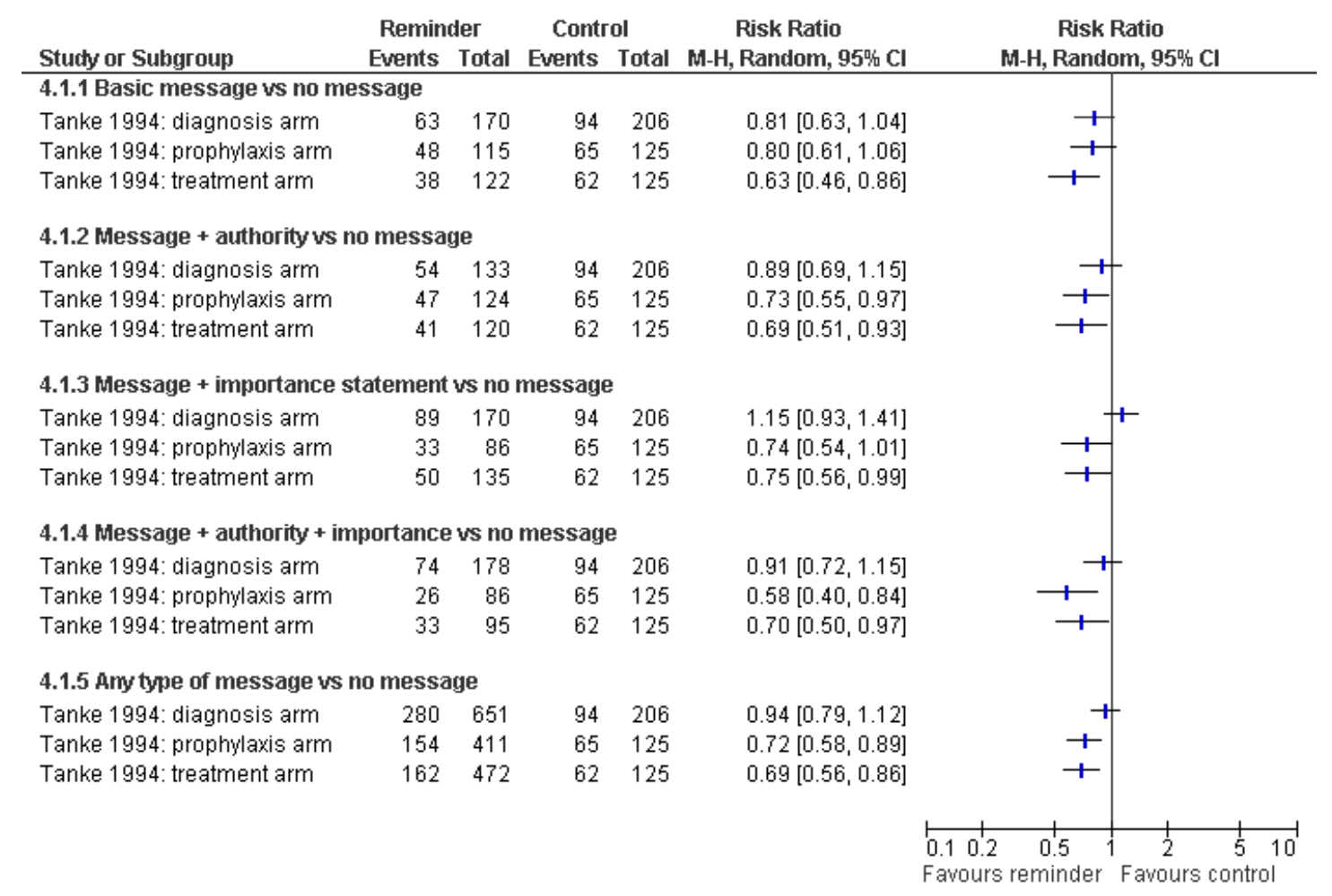

\subsection{Non-automated telephone reminder versus no reminder}

Cheng 1997 compared the effectiveness of a reminder phone call to parents of children aged one to 12 years on attendance for Mantoux test reading with no reminder. Fewer children whose parents received the reminder call failed to return for Mantoux test reading (RR $0.70,95 \%$ CI 0.50 to $0.99 ; 246$ participants, Analysis 5.1).

\subsection{Reminder plus health education versus usual care}

Sanmarti 1993 evaluated a telephone call reminder and home visit by specialized nursing personnel every three months on the adherence to tuberculosis chemoprophylaxis in school children. The data on attendance at the last visit showed that both a telephone call reminder (RR $0.18,95 \%$ CI 0.07 to $0.44 ; 157$ participants) and home visit reminder (RR $0.14,95 \%$ CI 0.05 to $0.39 ; 156$ participants) significantly improved the attendance at the final appointment compared with the control group; see Figure 4 and Analysis 6.1. 
Figure 4. Reminder plus health education vs usual care: Non-adherence to final clinic appointment

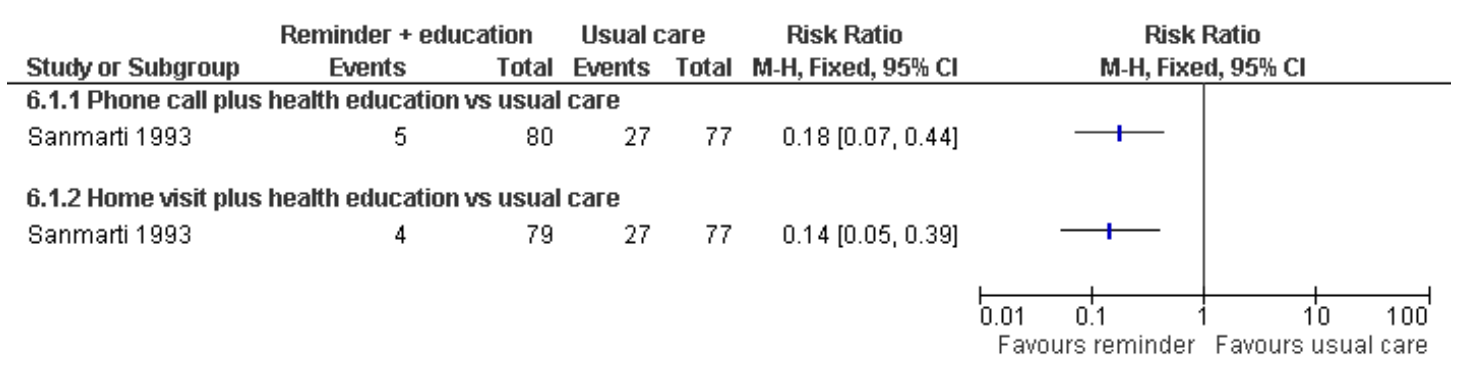

Forty-three participants withdrew from treatment; the reasons for their withdrawal and their allocation intervention group were not clear.

\subsection{Comparisons of various reminder formats}

Two trials were reported in one article; both were experiments with a factorial design in volunteers (mainly college students). The first experiment assessed four methods of providing return reminders (postcard, telephone call, direct person-to-person, or take-home card) in combination with two types of authority sources (expert versus non-expert) (Roberts 1983i). The data on return showed no significant difference in non-attendance at clinic appointments between participants who received reminders from experts and those who received reminders from non-experts (200 participants, Analysis 7.1), or between reminders delivered as a take-home card, a postcard, a telephone call, or person-to-person message (Analysis 7.1). The second experiment assessed combinations of types of patient commitment (verbal, verbal plus written, or no commitment) with importance-of-returning message (enhanced versus standard) as well as with two types of return reminders (take-home card versus no reminder) (Roberts 1983ii). The return rate for participants who received take-home card reminders was $70.9 \%$ while the return rate for those who received no reminders was $72.0 \%$, which showed no difference in non-attendance to clinic appointments between reminder group and control group (553 participants, Analysis 7.2).

\section{DISCUSSION}

Nine trials, reported in eight papers, were included in this review. Three assessed the use of late patient tracers and the other six assessed reminder systems.

For late patient tracers, two RCTs carried out in India and Iraq compared late patient tracer actions (letters and home visits, respectively) with usual care in people being treated for tuberculosis. Another RCT, also carried out in India, compared letters with home visits. The size of trials was relatively small, ranging from around 80 to 240 participants in each group, while the risk of bias in the trials varied; generation of allocation sequence and allocation concealment were not clear in one trial, while the other two trials had adequate allocation sequence generation and concealment. We could not pool the study results statistically as there was heterogeneity in the type of interventions, study design, settings, and outcomes.

The results favoured late patient tracer actions (home visit and letter) compared with no late patient tracer, with reported beneficial effects being both statistically and clinically significant. It is worth noting that the use of letters appeared to be effective in encouraging participants to return to treatment, even in those who were illiterate. There is inadequate evidence to show differences between different types of late patient tracers (ie home visit versus letter).

For reminders, almost all the trials were carried out in the USA except one trial carried out in Spain. There is currently no good quality research evidence on reminders available from developing countries, where the burden of tuberculosis is highest and where the resources available to both health services and patients are different. Two quasi-RCTs, using day of the week as an alternative to randomization, assessed the use of reminders. One was conducted within a screening programme and reminded people to attend for skin test readings, and the other within three different clinics, covering diagnosis, prophylaxis, and treatment. Two RCTs (reported in one paper) used volunteers for a university-sponsored tuberculosis detection drive, while another two assessed the use of reminders in people undergoing a tuberculin skin test and in primary school children who were on tuberculosis chemoprophylaxis, respectively.

The size of trials assessing reminders varied widely from around 50 participants to more than 400 in each group. The risk of bias in the trials was generally low; two were quasi-randomized while the other four were described as randomized, but it was unclear how the allocation sequences were generated and whether the allocation 
concealment was adequate. None of the trials mentioned whether they took any measures to prevent the control group from receiving the interventions. We could not pool the study results statistically because there was heterogeneity in the types of interventions, study design, settings, and outcomes.

The results of the trials using reminders were varied. In one RCT, within the slightly artificial context of a university-sponsored tuberculosis detection drive, the number of participants returning for Mantoux test reading was no different whether they were given a take-home reminder card or not. In another experiment, carried out at the same place and time, there was no significant difference in return rates between reminders given as a take-home card, a posted card, telephone reminders, or reminders given in person before the participants left the clinic after being given the test, although point estimates were in favour of telephone and person-to-person reminders when compared with written reminders. In two trials (one quasi-randomized) based in real clinic settings, significantly fewer participants missed appointments for skin test reading in the group receiving telephone reminders (including automated telephone reminders). In the other quasi-randomized trial, automated telephone reminders for the diagnosis clinic had no significant effect, but significantly fewer participants from the prophylaxis and treatment clinics who received reminders missed their appointments. In the trial with the co-intervention of health education, significantly fewer participants missed the clinic appointments for tuberculosis chemoprophylaxis.

It is important to note that studies that used bundled interventions were excluded from this review (Thiam 2007). Excluding studies that used packaged or multiple interventions implemented under programme conditions limits the generalizability of this review. This also highlights the difficulty of doing systematic reviews of trials that test multiple or combined interventions to improve adherence to long-term treatment regimens. Future reviews should consider the implementation of interventions under programme settings. Sustainability and duration of effectiveness of the interventions are other important factors to consider in assessing the effectiveness of healthcare interventions aimed at improving adherence. Strategies to improve patient adherence can be divided into patient-oriented, provider-oriented, and system interventions.

The beneficial effects shown in the trials combining late patient tracers or reminders with additional health education suggest that late patient tracers or reminders may be particularly effective when used in combination with additional education or information for patients. However, the risk of bias in the studies warrants further studies with improved study design. In particular, more attention should be given to the measurement of actual patient outcomes, such as the incidence of active tuberculosis (in prophylaxis studies), tuberculosis cure (in treatment studies), and patient satisfaction.

Almost all the trials were conducted before or during the 1990s, when DOT, short-course (DOTS) was not yet widely practised.
Only one trial was carried out under the DOTS strategy (Mohan 2003). This trial reported a significant improvement in return for treatment and treatment success in the intervention group (home visit and health education for late patients) compared with usual care, even though the rates of return $(82.5 \%)$ and treatment success $(76.7 \%)$ were also quite high in the control group. This suggests that late patient tracer actions may be effective within a good quality DOTS strategy. More studies assessing the use of late patient tracers and reminders under the DOTS strategy are needed.

A Cochrane systematic review of patient reminders and recall systems for improving immunization rates likewise showed that all types of reminders were effective (postcards, letters, telephone, or autodialer calls), with telephone being the most effective but most costly (Vann 2005). All trials, however, were from developed countries only. On the other hand, the Cochrane systematic review of DOT for tuberculosis showed no significant difference between DOT and self-administered therapy in terms of treatment cure and completion rates (Volmink 2007).

\section{A U T HOR S, CONCLUSIONS Implications for practice}

There are different types of late patient tracer actions and reminders being applied to improve adherence to tuberculosis clinic appointments. Despite the limitations of the included studies in terms of type of intervention, methodology, settings, and outcomes, the results show favourable and significantly better outcomes among those patients for whom late patient tracers or reminders are used. Late patient tracers (home visit and letter) are potentially useful in increasing adherence to tuberculosis treatment, and hence improving outcomes for individuals and the community. The results from almost all the reminder trials, except one, show benefits of different types of reminders compared to no reminder on adherence to tuberculosis clinic appointments.

Different types of late patient tracers and reminders can be tailored to suit specific provider and practice needs. Based on current research findings, there is not enough evidence to assess the differences between different types of late patient tracers and reminders. When choosing the type of late patient tracers and reminders, some practical issues also need to be considered, such as staffing, transportation, health facilities, perceived accuracy of patient telephone numbers or addresses, availability of computer programmers, and estimated patient responses to different types of late patient tracers and reminders. Practitioners need to consider their own settings when interpreting the findings in this review since these factors vary widely across nations or geographic regions. 


\section{Implications for research}

For late patient tracers, more good quality trials are needed to decide the most effective late patient tracer actions in different settings. Any future trials need to record carefully the study design, setting, the details of the intervention, and also the resource implications. More updated trials within the DOTS strategy are needed to confirm the effectiveness of late patient tracers.

For reminders, due to the poor quality of evidence, more welldesigned trials are needed to establish whether reminders are effective in different settings, and the best way of delivering reminders, especially in developing countries. Specifically, future trials should describe carefully the study design, setting, and the details of the intervention, and report primary/clinical health outcomes of the patients. There are no RCTs of reminders carried out in chemoprophylaxis or treatment settings, and considering the importance of adherence to chemoprophylaxis and treatment appointments, such studies would be very useful.

\section{ACKNOWLEDGEMENTS}

This review is an output from a project funded by the UK Department for International Development (DFID) for the benefit of developing countries. The views expressed are not necessarily those of DFID.

\section{REFERENCES}

\section{References to studies included in this review}

Cheng 1997 \{published data only\}

Cheng TL, Ottolini MC, Baumhaft K, Brasseux C, Wolf MD, Scheidt PC. Strategies to increase adherence with tuberculin test reading in a high-risk population. Pediatrics 1997;100(2):210-3.

Krishnaswami 1981 \{published data only\}

Krishnaswami KV, Somasundaram PR, Tripathy SP, Vaidyanathan B, Radhakrishna S, Fox WA. Randomised study of two policies for managing default in out-patients collecting supplies of drugs for pulmonary tuberculosis in a large city in South India. Tubercle 1981;62(2):103-12.

Mohan 2003 \{published data only\}

Mohan A, Nassir H, Niazi A. Does routine home visiting improve the return rate and outcome of DOTS patients who delay treatment?. Eastern Mediterranean Health Journal 2003;9(4):702-8.

Paramasivan 1993 \{published data only\}

Paramasivan R, Parthasarathy RT, Rajasekaran S. Short course chemotherapy: A controlled study of indirect defaulter retrieval method. Indian Journal of Tuberculosis 1993;40(4):185-90.
Roberts 1983i \{published data only\}

Roberts MC. Wurtele SK. Leeper JD. Experiments to increase return in a medical screening drive: two futile attempts to apply theory to practice. Social Science \& Medicine 1983;17(11):741-6.

Roberts 1983ii \{published data only\} Roberts MC. Wurtele SK. Leeper JD. Experiments to increase return in a medical screening drive: two futile attempts to apply theory to practice. Social Science \& Medicine 1983;17(11):741-6.

Sanmarti 1993 \{published data only\} Sanmarti LS, Megias JA, Gomez MN, Soler JC, Alcala EN, Sune $\mathrm{MR}$, et al.Evaluation of the efficacy of health education on the compliance with antituberculosis chemoprophylaxis in school children. A randomized clinical trial. Tubercle and Lung Disease 1993;74(1):28-31.

Tanke 1994 \{published data only\} Tanke ED, Leirer VO. Automated telephone reminders in tuberculosis care. Medical Care 1994;32(4):380-89.

Tanke 1994: diagnosis arm \{published data only\} See Tanke 1994.

Tanke 1994: prophylaxis arm \{published data only\} See Tanke 1994 
Tanke 1994: treatment arm \{published data only\}

See Tanke 1994.

Tanke 1997 \{published data only\}

Tanke ED, Martinez CM, Leirer VO. Use of automated reminders for tuberculin skin test return. American Journal of Preventive

Medicine 1997;13(3):189-92.

\section{References to studies excluded from this review}

\section{AL-Hajjaj 2000 \{published data only\}}

Al-Hajjaj MS, Al-Khatim IM. High rate of non-compliance with anti-tuberculosis treatment despite a retrieval system: a call for implementation of directly observed therapy in Saudi Arabia. International Journal of Tuberculosis and Lung Disease 2000;4(4): 345-9.

Alcaide Megías 1990 \{published data only\}

Alcaide Megías J, Altet Gómez MN, Canela Soler J, Serra Majen L, Garrido Morales P, Navas Alcalá E, et al.Influence of health education on compliance with antituberculous chemoprophylaxis in children: a community trial [Influencia de la educaci $囚 n$ sanitaria en el cumplimiento de la quimioprofilaxis antituberculosa en ninos: ensayo comunitario]. Revista Clínica Española 1990;187(2):89-93.

\section{Bordley 2001 \{published data only\}}

Bordley WC, Margolis PA, Stuart J, Lannon C, Keyes L. Improving preventive service delivery through office systems. Pediatrics 2001; 108(3):41-8.

Gordillo 2003 \{published data only\}

Gordillo AGC, Gordillo AJF, Jimenez DJ.E. Educational strategy for improving patient compliance with the tuberculosis treatment regimen in Chiapas, Mexico [Estrategia educativa para incrementar el cumplimiento del regimen antituberculoso en Chiapas, Mexico]. Pan American Journal of Public Health 2003;14(6):402-8.

\section{Hovell 2003 \{published data only\}}

Hovell MF, Sipan CL, Blumberg EJ, Hofstetter CR, Slymen D, Friedman L, et al.Increasing Latino adolescents' adherence to treatment for latent tuberculosis infection: a controlled trial. American Journal of Public Health 2003;93(11):1871-7.

Jin 1993 \{published data only\}

Jin BW, Kim SC, Mori T, Shimao T. The impact of intensified supervisory activities on tuberculosis treatment. Tubercle and Lung Disease 1993;74(4):267-72.

Krishna 2002 \{published data only\} Krishna S, Balas EA, Boren SA, Maglaveras N. Patient acceptance of educational voice messages: a review of controlled clinical studies. Methods of Information in Medicine 2002;41(5):360-9.

\section{Lin 2006 \{published data only\}}

Lin RL, Lin FJ, Wu CL, Peng MJ, Chen PJ, Kuo HT. Effect of a hospital-based case management approach on treatment outcome of patients with tuberculosis. Journal of the Formosan Medical Association 2006;105(8):636-44.

Morisky 1990 \{published data only\} Morisky DE, Malotte CK, Choi P, Davidson P, Rigler S, Sugland B, et al.A patient education program to improve adherence rates with antituberculosis drug regimens. Health Education Quarterly 1990; 17(3):253-67.
Morisky 2001 \{published data only\}

Morisky DE, Malotte CK, Ebin V, Davidson P, Cabrera D, Trout $\mathrm{PT}$, et al.Behavioral interventions for the control of tuberculosis among adolescents. Public Health Reports 2001;116(6):568-74.

Nyamathi 2007 \{published data only\}

Nyamathi A. Stein JA. Schumann A, Tyler D. Latent variable assessment of outcomes in a nurse-managed intervention to increase latent tuberculosis treatment completion in homeless adults. Health Psychology 2007;26(1):68-76.

Thiam 2007 \{published data only\}

Thiam S, LeFevre AM, Hane F, Ndiaye A, Ba F, Fielding KL, et al.Effectiveness of a strategy to improve adherence to tuberculosis treatment in a resource-poor setting: a cluster randomized controlled trial. JAMA 2007;297(4):380-6.

\section{Additional references}

\section{Bosch Capblanch 2007}

Bosch-Capblanch X, Abba K, Prictor M, Garner P. Contracts between patients and healthcare practitioners for improving patients' adherence to treatment, prevention and health promotion activities. Cochrane Database of Systematic Reviews 2007, Issue 2. [DOI: 10.1002/14651858.CD004808.pub3]

\section{Goble 1993}

Goble M, Iseman MD, Madsen LA. Treatment of 171 patients with pulmonary tuberculosis resistant to isoniazid and rifampin. New England Journal of Medicine 1993;328(8):527-32.

\section{Green 2003}

Green D. ICT-enabled development case studies series: The compliance service uses SMS technology for TB treatment. www.bridges.org/case' studies/137 2003 (accessed 1 September 2006).

Haynes 2008

Haynes RB, Ackloo E, Sahota N, McDonald HP, Yao X. Interventions for enhancing medication adherence. Cochrane Database of Systematic Reviews 2008, Issue 2. [DOI: DOI: 10.1002/ 14651858.CD000011.pub3]

\section{Jagota 1996}

Jagota P, Sreenivas TR, Parimala N. Improving treatment compliance by observing difference in treatment irregularity. Indian Journal of Tuberculosis 1996;43:75-80.

\section{Johansson 1999}

Johansson E, Long NH, Diwan VK, Winkvist A. Attitudes to compliance with tuberculosis treatment among women and men in Vietnam. International Journal of Tuberculosis and Lung Disease 1999;3(10):862-8.

\section{Jüni 2001}

Jüni P, Altman DG, Egger M. Systematic reviews in health care: Assessing the quality of controlled clinical trials. BMJ 2001;323 (7303):42-6.

\section{Lefebvre 2006}

Lefebvre C, Manheimer E, Glanville J. Chapter 6: Searching for studies. In: Higgins JPT, Green S (editors). Cochrane Handbook for Systematic Reviews of Interventions Version 5.0.0 (updated February 2008). The Cochrane Collaboration, 2008.. Available from www.cochrane-handbook.org. 


\section{M'Imunya 2007}

M'Imunya MJ, Volmink J. Education and counselling for promoting adherence to the treatment of active tuberculosis. Cochrane Database of Systematic Reviews 2007, Issue 3. [DOI: 10.1002/14651858.CD006591]

\section{Mitchison 1998}

Mitchison DA. How drug resistance emerges as a result of poor compliance during short course chemotherapy for tuberculosis. International Journal of Tuberculosis and Lung Disease 1998;2(1): $10-5$.

\section{O'Boyle 2002}

O’Boyle SJ, Power JJ, Ibrahim MY, Watson JP. Factors affecting patient compliance with anti-tuberculosis chemotherapy using the directly observed treatment, short-course strategy (DOTS).

International Journal of Tuberculosis and Lung Disease 2002;6(4): 307-12.

\section{Ormerod 1991}

Ormerod LP, Prescott RJ. Inter-relations between relapses, drug regimens and compliance with treatment in tuberculosis. Respiratory Medicine 1991;85(3):239-42.

\section{Review Manager 5}

The Nordic Cochrane Centre, The Cochrane Collaboration. Review Manager (RevMan). 5.0. Copenhagen: The Nordic Cochrane Centre, The Cochrane Collaboration, 2008.

\section{Thilakavathi 1993}

Thilakavathi S, Fredrick JS, Fredrick KG, Parthasarathy R, Santha $\mathrm{T}$. High coverage for long term follow-up of patients with spinal tuberculosis. Indian Journal of Tuberculosis 1993;40(2):91-4.

\section{Vann 2005}

Jacobson Vann JC, Szilagyi P. Patient reminder and recall systems to improve immunization rates. Cochrane Database of Systematic Reviews 2005, Issue 3. [DOI: 10.1002/ 14651858.CD003941.pub2]

\section{Volmink 2007}

Volmink J, Garner P. Directly observed therapy for treating tuberculosis. Cochrane Database of Systematic Reviews 2007, Issue 4. [DOI: 10.1002/14651858.CD003343.pub3]

\section{Weis 1994}

Weis SE, Slocum PC, Blais FX, King B, Nunn M, Matney GB, et al.The effect of directly observed therapy on the rates of drug resistance and relapse in tuberculosis. New England Journal of Medicine 1994;330(17):1179-84.

\section{WHO 2003a}

WHO Global Tuberculosis Programme. Treatment of tuberculosis: guidelines for national programmes [WHO/CDS/TB/2003.313]. 3rd Edition. Geneva: World Health Organization, 2003.

\section{WHO 2003b}

World Health Organization. Adherence to long term therapies: evidence for action. Geneva, Switzerland: World Health Organization, 2003.

\section{WHO 2006}

World Health Organization, Communicable Diseases Cluster. Global tuberculosis control: surveillance, planning, financing : WHO report 2006 [WHO/HTM/TB/2006.362]. Geneva: World Health Organization, 2006.

\section{WHO 2007}

World Health Organization. Global tuberculosis control: surveillance, planning, financing. WHO Report 2007. WHO/HTMI TB/2007.376. Geneva: World Health Organization, 2007.

\section{WHO 2008}

WHO/IUATLD Global Project on Anti-tuberculosis Drug Resistance Surveillance 2002?2007. Anti-tuberculosis drug resistance in the world. Report No. 4. Geneva, Switzerland: World Health Organization, 2008.

* Indicates the major publication for the study 
CHARACTERISTICS OF STUDIES

\section{Characteristics of included studies [ordered by study ID]}

\section{Cheng 1997}

\begin{tabular}{|c|c|}
\hline Methods & $\begin{array}{l}\text { Quasi-randomized controlled trial } \\
\text { Generation of allocation sequence: randomized by day of the week } \\
\text { Allocation concealment: unclear } \\
\text { Blinding of outcome assessors: unclear } \\
\text { Blinding of providers and participants: not possible } \\
\text { Inclusion of randomized participants in the analysis: } 627 / 627 \text { (100\%) } \\
\text { Protection against contamination: unclear }\end{array}$ \\
\hline Participants & $\begin{array}{l}\text { Number: } 627 \text { randomized } \\
\text { Inclusion criteria: consecutive children ages } 1 \text { to } 12 \text { years due for a tuberculosis test in an urban children's hospital } \\
\text { outpatient department; } 1 \text { child per family enrolled } \\
\text { Exclusion criteria: not stated }\end{array}$ \\
\hline Interventions & $\begin{array}{l}\text { Intervention of interest } \\
\text { 1. Reminder phone call (reminders included a written information sheet with the times to return; skin tests circled } \\
\text { in permanent marker and date of return stamped on mother's and child's hands) } \\
\text { Other interventions } \\
\text { 2. Positive reinforcement group (transportation tokens and toy on return) } \\
\text { 3. Negative reinforcement group (asked to leave school forms until they returned for test reading and were told that } \\
\text { the test would be repeated if not read on time) } \\
\text { 4. Parents trained to read the Mantoux tuberculosis test for induration or no induration, and a nurse home visit was } \\
\text { scheduled to verify results } \\
\text { Control } \\
\text { 5. Routine verbal and written instructions } \\
\text { All families received education regarding the importance of skin testing for tuberculosis and the need for follow up } \\
\text { to read the results. Instructions were given to return to the clinic in } 48 \text { to } 72 \text { hours }\end{array}$ \\
\hline Outcomes & Non-adherence to return visit for Mantoux test reading \\
\hline Notes & $\begin{array}{l}\text { Location: USA } \\
\text { Baseline data: comparable }\end{array}$ \\
\hline
\end{tabular}


Krishnaswami 1981

\begin{tabular}{|c|c|}
\hline Methods & $\begin{array}{l}\text { Randomized controlled trial } \\
\text { Generation of allocation sequence: unclear } \\
\text { Allocation concealment: unclear } \\
\text { Blinding of outcome assessors: unclear } \\
\text { Blinding of providers and participants: not possible } \\
\text { Inclusion of randomized participants in the analysis: } 150 / 170 \text { (89\%); } 20 \text { participants excluded from main analysis } \\
\text { because of death (8), lost to follow up (6), chemotherapy change (3), or transfer to more accessible clinics (3) } \\
\text { Protection against contamination: unclear }\end{array}$ \\
\hline Participants & $\begin{array}{l}\text { Number: } 170 \text { randomized; } 150 \text { analysed } \\
\text { Inclusion criteria: patients with symptoms reporting at the Institute of Tuberculosis and Chest Diseases in Madras; } \\
\text { with radiographic evidence of tuberculosis but negative smears; aged } \geq 12 \text { years; prescribed national tuberculosis } \\
\text { programme recommended regimen; living within a radius of about } 5 \mathrm{~km} \text { from the clinic; bona fide residents of } \\
\text { Madras city and regarded as stable (expected to remain in the city for at least } 1 \text { year) } \\
\text { Exclusion criteria: not stated }\end{array}$ \\
\hline Interventions & $\begin{array}{l}\text { Intervention } \\
\text { 1. In the event of default, a health visitor went to the participant's home on the } 4^{\text {th }} \text { day to persuade the patient to } \\
\text { attend the clinic. If necessary, further visits were made on the } 11^{\text {th }} \text { day, and at } 1 \text { and } 2 \text { months. At one of the latter } \\
2 \text { visits, a doctor accompanied the health visitor if the latter had met the patient at an early visit but had failed to } \\
\text { persuade the patient to attend } \\
\text { Control } \\
\text { 2. In the event of default, a reminder letter in Tamil (the local language) asking the patient to attend the clinic was } \\
\text { posted to the home address on the evening of the } 4^{\text {th }} \text { day. If the patient still failed to attend, a health visitor went to } \\
\text { the home on the } 11^{\text {th }} \text { day to see the patient personally and persuade him/her to attend }\end{array}$ \\
\hline Outcomes & $\begin{array}{l}\text { 1. Failure to retrieve the defaulters with the first action for the first episode of default } \\
\text { 2. Failure to retrieve the defaulters with the first action for all episodes of default } \\
\text { 3. Mean number of drug collections for one year } \\
\text { 4. Patients who discontinued treatment prematurely } \\
\text { 5. Number of episodes of default }\end{array}$ \\
\hline Notes & $\begin{array}{l}\text { Location: South India } \\
\text { Baseline data: comparable } \\
\text { Default: defined by the trial authors as failure of the patient to collect his/her supply of drugs on the due date or } \\
\text { within the next } 3 \text { days }\end{array}$ \\
\hline
\end{tabular}

\section{Mohan 2003}

Methods Randomized controlled trial

Generation of allocation sequence: random-numbers table

Allocation concealment: sequentially numbered and sealed opaque envelopes

Blinding of outcome assessors: yes

Blinding of providers and participants: not possible

Inclusion of randomized participants in the analysis: $480 / 480$ (100\%)

Protection against contamination: done 
Mohan 2003 (Continued)

\begin{tabular}{l|l} 
Participants & $\begin{array}{l}\text { Number: } 480 \text { randomized } \\
\text { Inclusion criteria: new smear-positive pulmonary tuberculosis (PTB); never been treated previously; delayed coming } \\
\text { to collect drugs at the health centre for at least } 3 \text { days after scheduled appointment; identified from official patient } \\
\text { record cards } \\
\text { Exclusion criteria: re-treatment patients }\end{array}$ \\
\hline Interventions & $\begin{array}{l}\text { Intervention } \\
\text { 1. Home visit by a local female volunteer from a local nongovernmental organization who was trained to motivate } \\
\text { patient to attend health centre daily and to give health education (co-intervention)for the patient and his/her family } \\
\text { Control } \\
\text { 2. No home visit }\end{array}$ \\
\hline Outcomes & $\begin{array}{l}\text { 1. Patient who did not complete treatment } \\
\text { 2. Treatment interrupted for } \geq 2 \text { consecutive months } \\
\text { 3. Treatment failure: patient who is sputum positive at } 5 \text { months or later during treatment } \\
\text { 4. Death } \\
\text { 5. Sputum smear positive follow up }\end{array}$ \\
\hline Notes & $\begin{array}{l}\text { Location: Iraq } \\
\text { Baseline data: not reported } \\
\text { Default: defined by the author as treatment interrupted for } \geq 2 \text { consecutive months }\end{array}$ \\
\hline
\end{tabular}

\section{Paramasivan 1993}

\begin{tabular}{l|l} 
Methods & $\begin{array}{l}\text { Randomized controlled trial } \\
\text { Generation of allocation sequence: random-numbers table } \\
\text { Allocation concealment: centralized randomization by a third party } \\
\text { Blinding of outcome assessors: no } \\
\text { Blinding of providers and participants: no } \\
\text { Inclusion of randomized participants in the analysis: 200/200 (100\%) } \\
\text { Protection against contamination: done }\end{array}$ \\
\hline Participants & $\begin{array}{l}\text { Number: } 200 \text { randomized } \\
\text { Inclusion criteria: newly diagnosed adult pulmonary tuberculosis patients; sputum positive for acid-fast bacilli (AFB); } \\
\text { no treatment or }<15 \text { days previous treatment; not in moribund condition or suffering from disorders like diabetes, } \\
\text { cardiac failure, or renal failure; willing to stay in the hospital for the initial 1-month intensive phase of treatment } \\
\text { Exclusion criteria: not stated }\end{array}$ \\
\hline Interventions & $\begin{array}{l}\text { Intervention } \\
\text { 1. First indirect defaulter action was posting of a reminder letter to the correct home address on the } 4^{\text {th }} \text { day of the } \\
\text { due date. The second defaulter action became due only when the first action failed to retrieve the patient, and it } \\
\text { would be posted on the } 8^{\text {th }} \text { day after the first action. } \\
\text { Control } \\
\text { 2. No reminder letter }\end{array}$ \\
\hline $\begin{array}{l}\text { 1. Number of patients who did not complete treatment } \\
\text { 2. Number of patients who did not complete the treatment in spite of defaulter retrieval } \\
\text { 3. Defaulters retrieval }\end{array}$ \\
\hline Outcomes
\end{tabular}




\section{Paramasivan 1993 (Continued)}

\begin{tabular}{ll}
\hline Notes & Location: South India \\
Baseline data: not reported \\
$\begin{array}{l}\text { Defaulter defined by author as a patient who failed to collect the drugs within } 3 \text { days after the due date of drug } \\
\text { collection }\end{array}$ \\
\hline
\end{tabular}

\section{Roberts 1983i}

\begin{tabular}{|c|c|}
\hline Methods & $\begin{array}{l}\text { Randomized controlled trial } \\
\text { Generation of allocation sequence: unclear } \\
\text { Allocation concealment: unclear } \\
\text { Blinding of outcome assessors: unclear } \\
\text { Blinding of providers and participants: not possible } \\
\text { Inclusion of all randomized participants in the analysis: 200/200 (100\%) } \\
\text { Protection against contamination: unclear }\end{array}$ \\
\hline Participants & $\begin{array}{l}\text { Number: } 200 \text { randomized } \\
\text { Inclusion criteria: volunteers who participated in a university-sponsored tuberculosis detection drive; mostly college } \\
\text { students } \\
\text { Exclusion criteria: not stated }\end{array}$ \\
\hline Interventions & $\begin{array}{l}\text { Intervention } \\
\text { 1. Take-home card } \\
\text { 2. Postcard } \\
\text { 3. Telephone call } \\
\text { Control } \\
\text { Direct person-to-person reminder }\end{array}$ \\
\hline Outcomes & Number of participants who fail to return for skin-test reading \\
\hline Notes & $\begin{array}{l}\text { Location: USA } \\
\text { Baseline data: comparable }\end{array}$ \\
\hline
\end{tabular}

\section{Roberts 1983ii}

\begin{tabular}{|c|c|}
\hline Methods & $\begin{array}{l}\text { Randomized controlled trial } \\
\text { Generation of allocation sequence: unclear } \\
\text { Allocation concealment: unclear } \\
\text { Blinding of outcome assessors: unclear } \\
\text { Blinding of providers and participants: not possible } \\
\text { Inclusion of all randomized participants in the analysis: } 553 / 553(100 \%) \\
\text { Contamination: unclear }\end{array}$ \\
\hline Participants & $\begin{array}{l}\text { Number: } 553 \text { randomized } \\
\text { Inclusion criteria: volunteers who participated in a university-sponsored tuberculosis detection drive } \\
\text { Exclusion criteria: not stated }\end{array}$ \\
\hline
\end{tabular}




\section{Roberts 1983ii (Continued)}

\begin{tabular}{ll} 
Interventions & $\begin{array}{l}\text { Intervention } \\
\text { 1. Take-home card with or without enhanced message on the importance of returning, and with or without three } \\
\text { types of overt commitment to return } \\
\text { Control } \\
\text { 2. No reminder card }\end{array}$ \\
\hline Outcomes & Number of participants who fail to return for skin-test reading \\
\hline Notes & $\begin{array}{l}\text { Location: USA } \\
\text { Baseline data: comparable }\end{array}$ \\
\hline
\end{tabular}

\section{Sanmarti 1993}

\begin{tabular}{|c|c|}
\hline Methods & $\begin{array}{l}\text { Randomized controlled trial } \\
\text { Generation of allocation sequence: unclear } \\
\text { Allocation concealment: unclear } \\
\text { Blinding of outcome assessors: unclear } \\
\text { Blinding of providers and participants: not possible } \\
\text { Inclusion of randomized participants in the analysis: } 275 / 318 \text { (85\%); 43/318 (13.5\%) withdrew from treatment } \\
\text { Protection against contamination: unclear }\end{array}$ \\
\hline Participants & $\begin{array}{l}\text { Number: } 318 \text { randomized } \\
\text { Inclusion criteria: school children of both sexes in the first year of primary school in state-run and private schools in } \\
\text { the provinces of Barcelona, on anti-tuberculosis chemoprophylaxis } \\
\text { Exclusion criteria: children with active tuberculosis confirmed by medical examination and chest x-ray }\end{array}$ \\
\hline Interventions & $\begin{array}{l}\text { Intervention of interest } \\
\text { 1. Childrens' mothers were telephoned by a specialized nursing personnel every } 3 \text { months who informed them of } \\
\text { the advantages of chemoprophylaxis for their child's health and encouraged them to continue with this preventive } \\
\text { measure } \\
\text { Other interventions } \\
\text { 2. Specialized nurse went to the patient's home every } 3 \text { months providing health education to the mother and child, } \\
\text { encouraging them to continue with the preventive therapy, and giving them the same information leaflets given at } \\
\text { the first visit } \\
\text { 3. Child was seen by the physician every } 3 \text { months at the TB Prevention and Control Centre, providing health } \\
\text { education and leaflets at each visit } \\
\text { Control } \\
\text { 4. No health education activity performed }\end{array}$ \\
\hline Outcomes & $\begin{array}{l}\text { 1. Non-adherence to final appointment } \\
\text { 2. Negative Eidus-Hamilton reaction }\end{array}$ \\
\hline Notes & $\begin{array}{l}\text { Location: Spain } \\
\text { Baseline data: not reported }\end{array}$ \\
\hline
\end{tabular}


Tanke 1994

Methods Quasi-randomized controlled trial
Generation of allocation sequence: within each 5-week period each message variation was used once on each weekday,
different variations were used each day of a given week by a computer-generated system
Allocation concealment: unclear
Blinding of outcome assessors: unclear
Blinding of providers and participants: not possible
Inclusion of randomized participants in the analysis: 2008/2008 (100\%)
Protection against contamination: unclear

Participants Number: 2008 randomized

Inclusion criteria: patients with scheduled appointments in the Tuberculosis Control Program of Santa Clara County Health Department over a period of 6 months

Exclusion criteria: not stated

Interventions Interventions

1. Basic reminder: pre-recorded message (TeleMinder system) from the county health department; identified the patient by name, indicated that the patient had an appointment the following day, and gave the address and phone number of the clinic twice; message could be repeated by remaining on the line; message did not refer to tuberculosis 2. Basic reminder plus authority endorsement: identified the Public Health Nurse at the Health Department as the source of the message

3. Basic reminder plus importance statement: following statement was inserted after the basic information: "Coming to this appointment is important so that you and your family will not become seriously ill."

4. Basic reminder plus importance statement plus authority endorsement

Control

5. No message

Appropriate recorded message was sent to patients between 1800 and 2100 the evening before the scheduled appointment. The system allows a message to be left on answering machines and to call back up to 5 times at half-hour intervals if patients' lines were busy or there was no answer after 8 rings. For households whose primary language was English, Spanish, Vietnamese, or Tagalog, the message was sent in that language

Outcomes Non-attendance for a scheduled appointment: if a patient had > 1 appointment during the course of the study, only data from the first appointment were included

Notes Location: USA

Baseline data: not reported

Tanke 1994: diagnosis arm

\begin{tabular}{l|l}
\hline Methods & Tanke 1994 results for patients in the Reactor Clinic for diagnosis \\
\hline Participants & - \\
\hline Interventions & - \\
\hline Outcomes - \\
\hline Notes & - \\
\hline
\end{tabular}


Tanke 1994: prophylaxis arm

\begin{tabular}{ll}
\hline Methods & Tanke 1994 results for patients in the INH [isoniazid] Clinic for prophylaxis \\
\hline Participants & - \\
\hline Interventions & - \\
\hline Outcomes - \\
\hline Notes
\end{tabular}

Tanke 1994: treatment arm

\begin{tabular}{l|l}
\hline Methods & Tanke 1994 results for patients in the Case Clinic for treatment \\
\hline Participants & - \\
\hline Interventions & - \\
\hline Outcomes $\quad-$ \\
\hline Notes
\end{tabular}

Tanke 1997

\begin{tabular}{ll} 
Methods & $\begin{array}{l}\text { Randomized controlled trial } \\
\text { Generation of allocation sequence: unclear } \\
\text { Allocation concealment: unclear } \\
\text { Blinding of outcome assessors: unclear } \\
\text { Blinding of providers and participants: not possible } \\
\text { Inclusion of randomized participants in the analysis: } 701 / 701 \text { (100\%) } \\
\text { Protection against contamination: unclear }\end{array}$ \\
\hline Participants & $\begin{array}{l}\text { Number: } 701 \text { randomized } \\
\text { Inclusion criteria: persons undergoing tuberculin skin test at the } 2 \text { largest clinics of Santa Clara (California)County } \\
\text { Immunization Program } \\
\text { Exclusion criteria: not stated }\end{array}$ \\
\hline Interventions & $\begin{array}{l}\text { Intervention } \\
\text { 1. Pre-recorded telephone reminder message (TeleMinder system) between } 1800 \text { and } 2100 \text { the evening before the day } \\
\text { on which they were to return to have their skin test read, and the information was repeated twice in the participant's } \\
\text { primary language } \\
\text { Control } \\
\text { 2. No reminder message }\end{array}$ \\
\hline Outcomes & $\begin{array}{l}\text { 1. Total return failures } \\
\text { 1.1. 2-day delay } \\
\text { 1.2. 3-day delay }\end{array}$ \\
\hline
\end{tabular}


Tanke 1997 (Continued)

$\begin{array}{ll}\text { Notes } & \text { Location: USA } \\ & \text { Baseline data: Not reported }\end{array}$

\section{Characteristics of excluded studies [ordered by study ID]}

\begin{tabular}{|c|c|}
\hline AL-Hajjaj 2000 & Case-control study design \\
\hline Alcaide Megías 1990 & Intervention did not include reminders or late patient tracers \\
\hline Bordley 2001 & $\begin{array}{l}\text { Most participants did not have need for screening, prophylaxis, or treatment for tuberculosis, and results for } \\
\text { the individuals in these categories were not presented separately }\end{array}$ \\
\hline Gordillo 2003 & Intervention did not include reminders or late patient tracers \\
\hline Hovell 2003 & Intervention did not include reminders or late patient tracers \\
\hline Jin 1993 & Intervention did not include reminders or late patient tracers \\
\hline Krishna 2002 & Review article \\
\hline Lin 2006 & Cohort study design \\
\hline Morisky 1990 & $\begin{array}{l}\text { Intervention did not include reminders or late patient tracers, except for those routinely provided and also } \\
\text { applied to the control group }\end{array}$ \\
\hline Morisky 2001 & Intervention did not include reminders or late patient tracers \\
\hline Nyamathi 2007 & $\begin{array}{l}\text { Process of late patient tracers not described, and the main objective was to assess predictors of latent tuberculosis } \\
\text { infection completion by using structural equation modelling among homeless adults }\end{array}$ \\
\hline Thiam 2007 & Reminders or late patient tracers not adequately described or systematically applied \\
\hline
\end{tabular}


DATA AND ANALYSES

Comparison 1. Late patient tracers vs no late patient tracer

\begin{tabular}{|c|c|c|c|c|}
\hline Outcome or subgroup title & $\begin{array}{l}\text { No. of } \\
\text { studies }\end{array}$ & $\begin{array}{c}\text { No. of } \\
\text { participants }\end{array}$ & Statistical method & Effect size \\
\hline $\begin{array}{l}1 \text { Patients who did not complete } \\
\text { treatment }\end{array}$ & 2 & & Risk Ratio (M-H, Fixed, 95\% CI) & Totals not selected \\
\hline $\begin{array}{l}\text { 1.1 Home visit plus health } \\
\text { education vs usual care (directly } \\
\text { observed therapy, short-course) }\end{array}$ & 1 & & Risk Ratio (M-H, Fixed, 95\% CI) & Not estimable \\
\hline $\begin{array}{l}1.2 \text { Reminder letter vs usual } \\
\text { care }\end{array}$ & 1 & & Risk Ratio (M-H, Fixed, 95\% CI) & Not estimable \\
\hline $\begin{array}{l}2 \text { Failure of patients to return to } \\
\text { treatment after first missed } \\
\text { appointment }\end{array}$ & 1 & & Risk Ratio (M-H, Fixed, 95\% CI) & Totals not selected \\
\hline
\end{tabular}

Comparison 2. Late patient tracers (home visit plus health education) vs usual care

\begin{tabular}{|c|c|c|c|c|}
\hline Outcome or subgroup title & $\begin{array}{l}\text { No. of } \\
\text { studies }\end{array}$ & $\begin{array}{c}\text { No. of } \\
\text { participants }\end{array}$ & Statistical method & Effect size \\
\hline $\begin{array}{l}1 \text { Patients who did not complete } \\
\text { treatment }\end{array}$ & 1 & & Risk Ratio (M-H, Fixed, 95\% CI) & Totals not selected \\
\hline $\begin{array}{l}2 \text { Treatment interrupted for } 2 \\
\text { consecutive months or more }\end{array}$ & 1 & & Risk Ratio (M-H, Fixed, 95\% CI) & Totals not selected \\
\hline 3 Treatment failure & 1 & & Risk Ratio (M-H, Fixed, 95\% CI) & Totals not selected \\
\hline 4 Death & 1 & & Risk Ratio (M-H, Fixed, 95\% CI) & Totals not selected \\
\hline 5 Sputum-smear positive follow up & 1 & & Risk Ratio (M-H, Fixed, 95\% CI) & Totals not selected \\
\hline 5.12 months & 1 & & Risk Ratio (M-H, Fixed, 95\% CI) & Not estimable \\
\hline 5.25 months & 1 & & Risk Ratio (M-H, Fixed, 95\% CI) & Not estimable \\
\hline 5.3 End of treatment & 1 & & Risk Ratio (M-H, Fixed, 95\% CI) & Not estimable \\
\hline
\end{tabular}

Comparison 3. Late patient tracers (home visit) vs letter

\begin{tabular}{lccc} 
Outcome or subgroup title & $\begin{array}{c}\text { No. of } \\
\text { studies }\end{array}$ & $\begin{array}{c}\text { No. of } \\
\text { participants }\end{array}$ & Statistical method \\
\hline $\begin{array}{l}\text { Patients who did not complete } \\
\text { treatment }\end{array}$ & 1 & Risk Ratio (M-H, Fixed, 95\% CI) & Totals not selected \\
$\begin{array}{l}2 \text { Failure of patients to return } \\
\text { for treatment after missed } \\
\text { appointment }\end{array}$ & 1 & Risk Ratio (M-H, Fixed, 95\% CI) & Totals not selected \\
\hline
\end{tabular}

Reminder systems and late patient tracers in the diagnosis and management of tuberculosis (Review)

Copyright ( 2008 The Cochrane Collaboration. Published by John Wiley \& Sons, Ltd. 


\begin{tabular}{|c|c|c|c|c|}
\hline Outcome or subgroup title & $\begin{array}{l}\text { No. of } \\
\text { studies }\end{array}$ & $\begin{array}{c}\text { No. of } \\
\text { participants }\end{array}$ & Statistical method & Effect size \\
\hline $\begin{array}{l}1 \text { Non-attendance at clinic } \\
\text { appointment }\end{array}$ & 3 & & Risk Ratio (M-H, Random, 95\% CI) & Totals not selected \\
\hline $\begin{array}{l}1.1 \text { Basic message vs no } \\
\text { message }\end{array}$ & 3 & & Risk Ratio (M-H, Random, 95\% CI) & Not estimable \\
\hline $\begin{array}{l}1.2 \text { Message + authority vs no } \\
\text { message }\end{array}$ & 3 & & Risk Ratio (M-H, Random, 95\% CI) & Not estimable \\
\hline $\begin{array}{l}1.3 \text { Message + importance } \\
\text { statement vs no message }\end{array}$ & 3 & & Risk Ratio (M-H, Random, 95\% CI) & Not estimable \\
\hline $\begin{array}{l}\text { 1.4 Message + authority + } \\
\text { importance vs no message }\end{array}$ & 3 & & Risk Ratio (M-H, Random, 95\% CI) & Not estimable \\
\hline $\begin{array}{l}1.5 \text { Any type of message vs no } \\
\text { message }\end{array}$ & 3 & & Risk Ratio (M-H, Random, 95\% CI) & Not estimable \\
\hline
\end{tabular}

Comparison 5. Reminders (non-automated reminder phone call) vs no reminder

\begin{tabular}{lccc} 
Outcome or subgroup title & $\begin{array}{c}\text { No. of } \\
\text { studies }\end{array}$ & $\begin{array}{c}\text { No. of } \\
\text { participants }\end{array}$ & Statistical method \\
\hline $\begin{array}{l}1 \text { Non-adherence to Mantoux test } \\
\text { reading }\end{array}$ & 1 & Risk Ratio (M-H, Fixed, 95\% CI) & Totals not selected \\
$\begin{array}{l}1.1 \text { Reminder phone call vs no } \\
\text { call }\end{array}$ & 1 & Risk Ratio (M-H, Fixed, 95\% CI) & Not estimable \\
\hline
\end{tabular}

Comparison 6. Reminder plus health education vs usual care

\begin{tabular}{lccc} 
Outcome or subgroup title & $\begin{array}{c}\text { No. of } \\
\text { studies }\end{array}$ & $\begin{array}{c}\text { No. of } \\
\text { participants }\end{array}$ & Statistical method \\
\hline $\begin{array}{l}\text { Non-adherence to final clinic } \\
\text { appointment }\end{array}$ & 1 & Risk Ratio (M-H, Fixed, 95\% CI) & Totals not selected \\
$\begin{array}{l}1.1 \text { Phone call plus health } \\
\text { education vs usual care }\end{array}$ & 1 & Risk Ratio (M-H, Fixed, 95\% CI) & Not estimable \\
$\begin{array}{l}1.2 \text { Home visit plus health } \\
\text { education vs usual care }\end{array}$ & 1 & Risk Ratio (M-H, Fixed, 95\% CI) & Not estimable \\
\hline
\end{tabular}


Comparison 7. Reminder vs other types of reminders and no reminder

\begin{tabular}{|c|c|c|c|c|}
\hline Outcome or subgroup title & $\begin{array}{l}\text { No. of } \\
\text { studies }\end{array}$ & $\begin{array}{c}\text { No. of } \\
\text { participants }\end{array}$ & Statistical method & Effect size \\
\hline $\begin{array}{l}1 \text { Failed to return for skin test } \\
\text { reading }\end{array}$ & 1 & & Risk Ratio (M-H, Fixed, 95\% CI) & Totals not selected \\
\hline 1.1 Expert vs non-expert & 1 & & Risk Ratio (M-H, Fixed, 95\% CI) & Not estimable \\
\hline $\begin{array}{l}\text { 1.2 Take-home card vs } \\
\text { postcard }\end{array}$ & 1 & & Risk Ratio (M-H, Fixed, 95\% CI) & Not estimable \\
\hline $\begin{array}{l}\text { 1.3 Take-home card vs } \\
\text { telephone call }\end{array}$ & 1 & & Risk Ratio (M-H, Fixed, 95\% CI) & Not estimable \\
\hline $\begin{array}{l}\text { 1.4 Take-home card vs person- } \\
\text { to-person }\end{array}$ & 1 & & Risk Ratio (M-H, Fixed, 95\% CI) & Not estimable \\
\hline 1.5 Postcard vs telephone call & 1 & & Risk Ratio (M-H, Fixed, 95\% CI) & Not estimable \\
\hline $\begin{array}{l}1.6 \text { Postcard vs person-to- } \\
\text { person }\end{array}$ & 1 & & Risk Ratio (M-H, Fixed, 95\% CI) & Not estimable \\
\hline $\begin{array}{l}1.7 \text { Telephone call vs person- } \\
\text { to-person }\end{array}$ & 1 & & Risk Ratio (M-H, Fixed, 95\% CI) & Not estimable \\
\hline $\begin{array}{l}2 \text { Failed to return for skin test } \\
\text { reading }\end{array}$ & 1 & & Risk Ratio (M-H, Fixed, 95\% CI) & Totals not selected \\
\hline
\end{tabular}

\section{Analysis I.I. Comparison I Late patient tracers vs no late patient tracer, Outcome I Patients who did not complete treatment.}

Review: Reminder systems and late patient tracers in the diagnosis and management of tuberculosis

Comparison: I Late patient tracers vs no late patient tracer

Outcome: I Patients who did not complete treatment

\begin{tabular}{rrrr} 
Study or subgroup & Usual care & Risk Ratio & Risk Ratio \\
$\mathrm{n} / \mathrm{N}$ & $\mathrm{n} / \mathrm{N}$ & $\mathrm{M}-\mathrm{H}$, Fixed,95\% $\mathrm{Cl}$ & $\mathrm{M}-\mathrm{H}, \mathrm{Fixed}, 95 \% \mathrm{Cl}$ \\
\hline
\end{tabular}

I Home visit plus health education vs usual care (directly observed therapy, short-course)

Mohan $2003 \quad 9 / 240 \quad 42 / 240$

$0.21[0.11,0.43]$

2 Reminder letter vs usual care

Paramasivan 1993

$12 / 100$

$27 / 100$ 
Analysis I.2. Comparison I Late patient tracers vs no late patient tracer, Outcome 2 Failure of patients to return to treatment after first missed appointment.

Review: Reminder systems and late patient tracers in the diagnosis and management of tuberculosis

Comparison: I Late patient tracers vs no late patient tracer

Outcome: 2 Failure of patients to return to treatment after first missed appointment

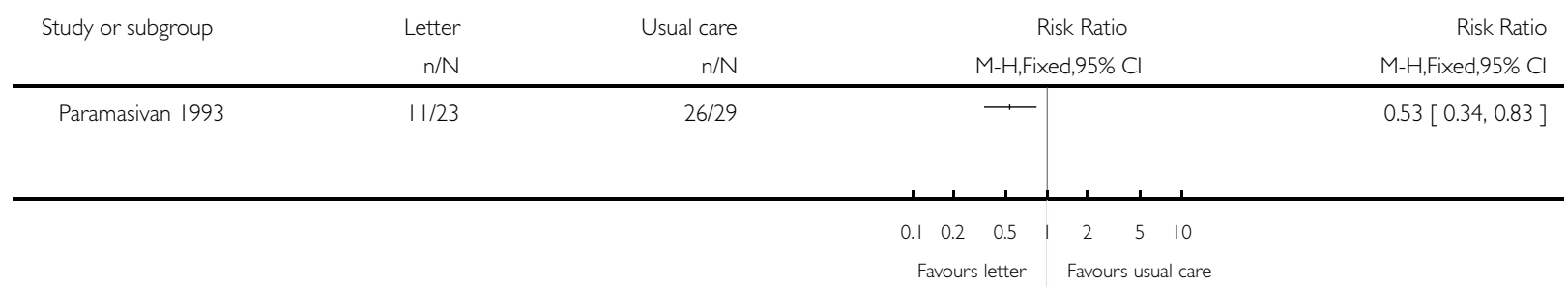

Analysis 2.I. Comparison 2 Late patient tracers (home visit plus health education) vs usual care, Outcome I Patients who did not complete treatment.

Review: Reminder systems and late patient tracers in the diagnosis and management of tuberculosis

Comparison: 2 Late patient tracers (home visit plus health education) vs usual care

Outcome: I Patients who did not complete treatment

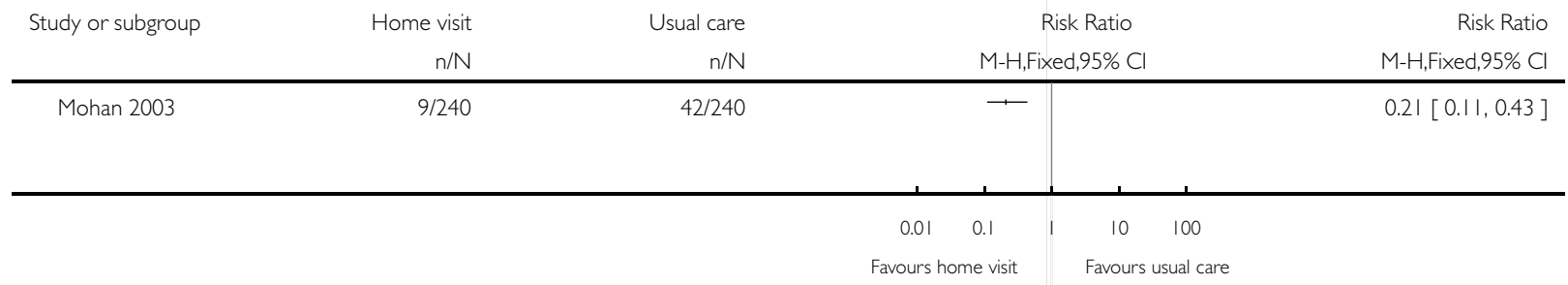


Analysis 2.2. Comparison 2 Late patient tracers (home visit plus health education) vs usual care, Outcome 2 Treatment interrupted for 2 consecutive months or more.

Review: Reminder systems and late patient tracers in the diagnosis and management of tuberculosis

Comparison: 2 Late patient tracers (home visit plus health education) vs usual care

Outcome: 2 Treatment interrupted for 2 consecutive months or more

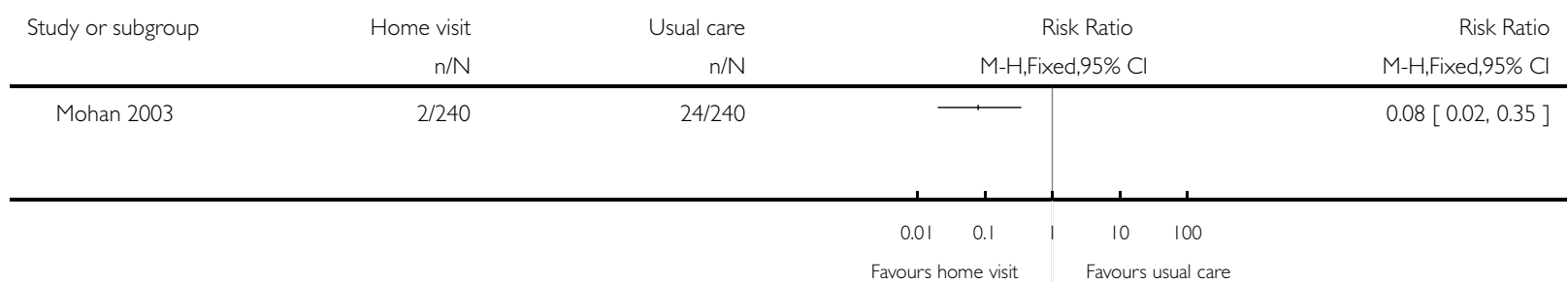

Analysis 2.3. Comparison 2 Late patient tracers (home visit plus health education) vs usual care, Outcome 3 Treatment failure.

Review: Reminder systems and late patient tracers in the diagnosis and management of tuberculosis

Comparison: 2 Late patient tracers (home visit plus health education) vs usual care

Outcome: 3 Treatment failure

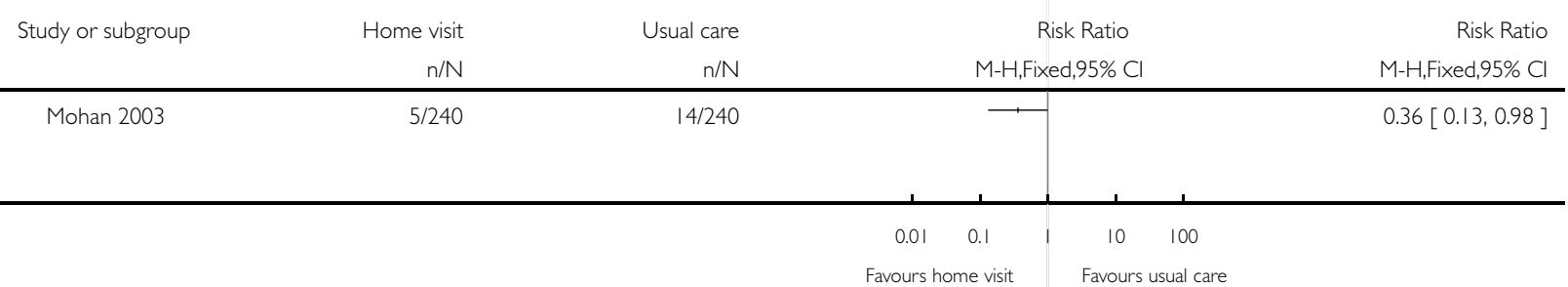


Analysis 2.4. Comparison 2 Late patient tracers (home visit plus health education) vs usual care, Outcome 4 Death.

Review: Reminder systems and late patient tracers in the diagnosis and management of tuberculosis

Comparison: 2 Late patient tracers (home visit plus health education) vs usual care

Outcome: 4 Death

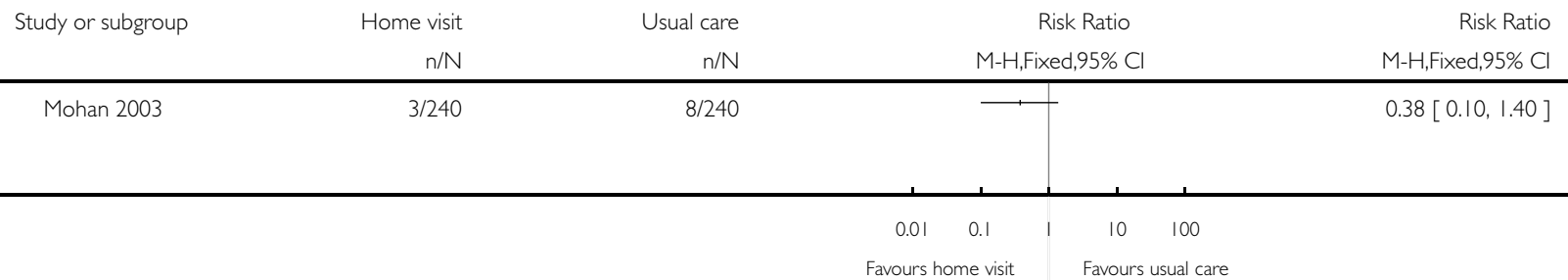

Analysis 2.5. Comparison 2 Late patient tracers (home visit plus health education) vs usual care, Outcome 5 Sputum-smear positive follow up.

Review: Reminder systems and late patient tracers in the diagnosis and management of tuberculosis

Comparison: 2 Late patient tracers (home visit plus health education) vs usual care

Outcome: 5 Sputum-smear positive follow up

$\begin{array}{rrrr}\text { Study or subgroup } & \text { Usual care } & \text { Risk Ratio } & \text { Risk Ratio } \\ \mathrm{n} / \mathrm{N} & \mathrm{n} / \mathrm{N} & \mathrm{M}-\mathrm{H}, \text { Fixed,95\% Cl } & \mathrm{M}-\mathrm{H}, \mathrm{Fixed}, 95 \% \mathrm{Cl}\end{array}$

\section{2 months}

Mohan 2003

$36 / 240$

$80 / 240$

$0.45[0.32,0.64]$

25 months

Mohan 2003

$24 / 240$

$68 / 240$

$0.35[0.23,0.54]$

3 End of treatment

Mohan 2003

$17 / 240$

$60 / 240$

$0.28[0.17,0.47]$

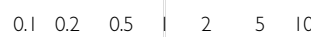

Favours home visit Favours usual care 
Analysis 3.I. Comparison 3 Late patient tracers (home visit) vs letter, Outcome I Patients who did not complete treatment.

Review: Reminder systems and late patient tracers in the diagnosis and management of tuberculosis

Comparison: 3 Late patient tracers (home visit) vs letter

Outcome: I Patients who did not complete treatment

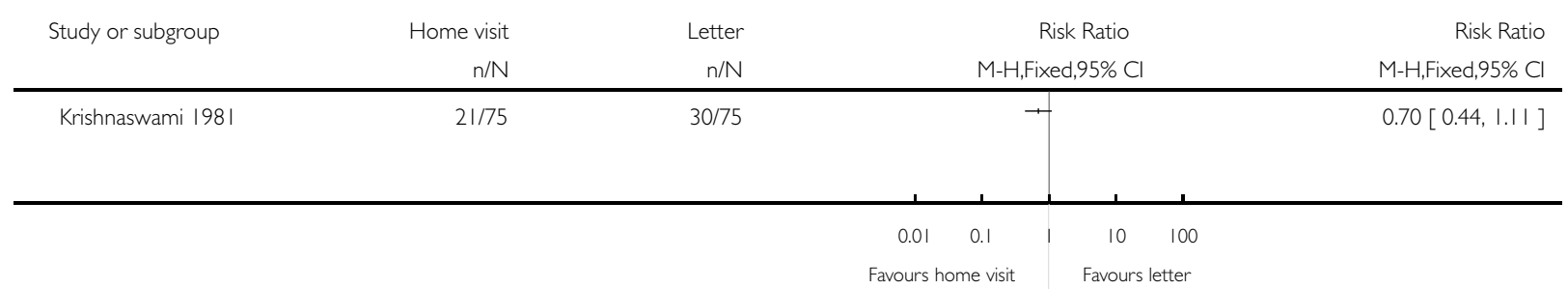

Analysis 3.2. Comparison 3 Late patient tracers (home visit) vs letter, Outcome 2 Failure of patients to return for treatment after missed appointment.

Review: Reminder systems and late patient tracers in the diagnosis and management of tuberculosis

Comparison: 3 Late patient tracers (home visit) vs letter

Outcome: 2 Failure of patients to return for treatment after missed appointment

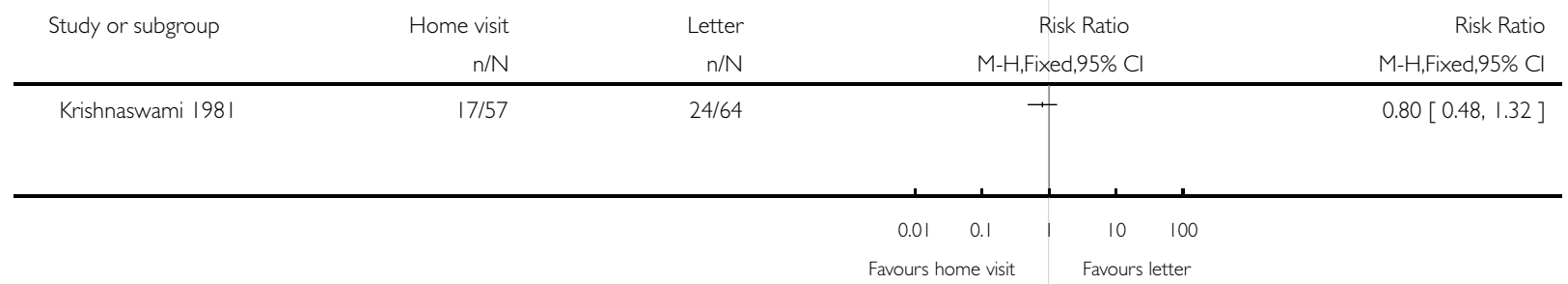


Analysis 4.I. Comparison 4 Reminders (automated telephone message) vs no message, Outcome I Nonattendance at clinic appointment.

Review: Reminder systems and late patient tracers in the diagnosis and management of tuberculosis

Comparison: 4 Reminders (automated telephone message) vs no message

Outcome: I Non-attendance at clinic appointment

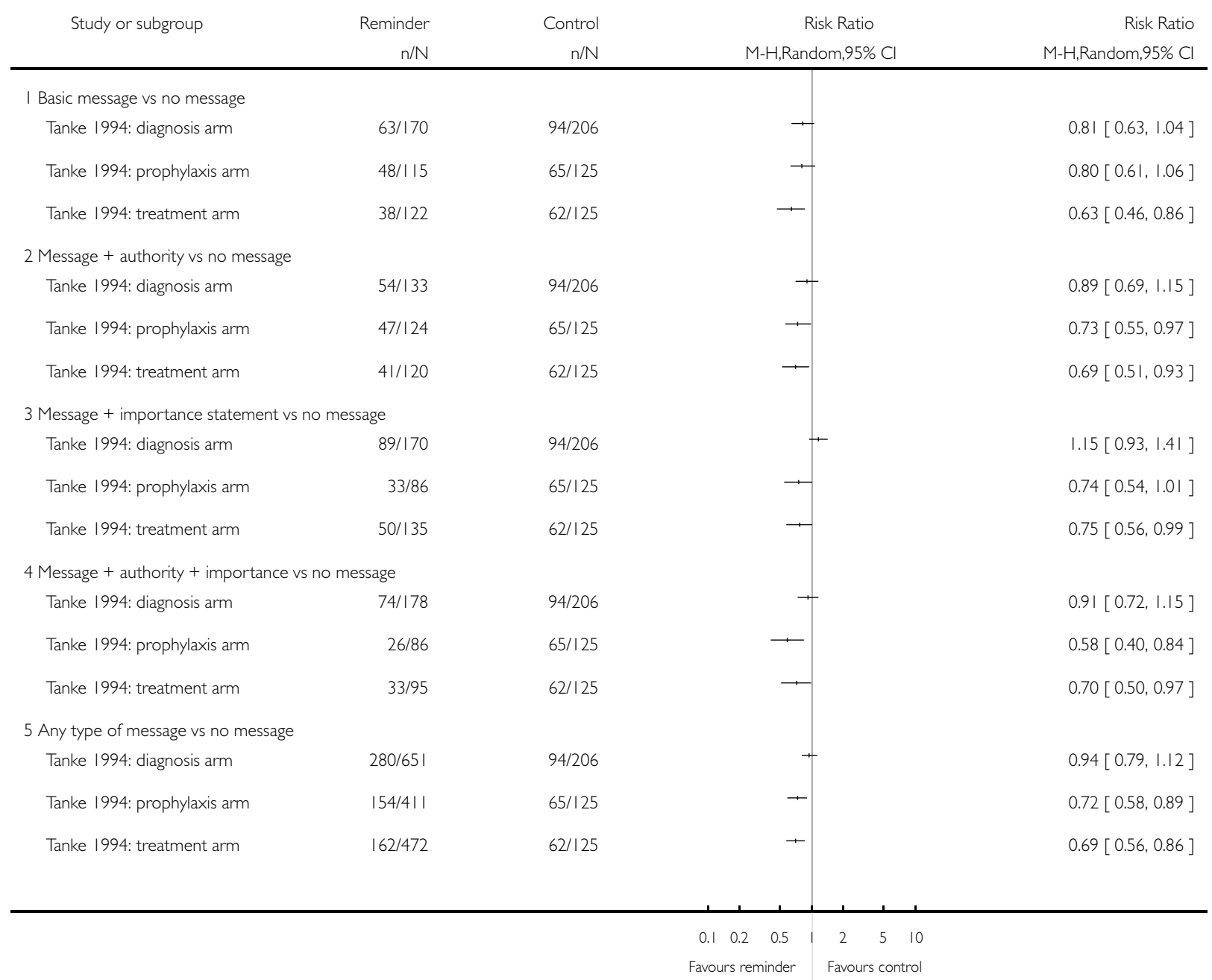


Analysis 5.I. Comparison 5 Reminders (non-automated reminder phone call) vs no reminder, Outcome I Non-adherence to Mantoux test reading.

\begin{tabular}{|c|c|c|c|c|}
\hline \multicolumn{5}{|c|}{ Comparison: 5 Reminders (non-automated reminder phone call) vs no reminder } \\
\hline \multicolumn{5}{|c|}{ Outcome: I Non-adherence to Mantoux test reading } \\
\hline \multirow[t]{2}{*}{ Study or subgroup } & Reminder phone call & Control & & Risk Ratio \\
\hline & $\mathrm{n} / \mathrm{N}$ & $n / N$ & M-H,Fixed,95\% Cl & M-H,Fixed,95\% Cl \\
\hline \multicolumn{5}{|c|}{ I Reminder phone call vs no call } \\
\hline Cheng 1997 & $37 / 125$ & $51 / 121$ & $\longrightarrow$ & $0.70[0.50,0.99]$ \\
\hline
\end{tabular}

Analysis 6.I. Comparison 6 Reminder plus health education vs usual care, Outcome I Non-adherence to final clinic appointment.

Review: Reminder systems and late patient tracers in the diagnosis and management of tuberculosis

Comparison: 6 Reminder plus health education vs usual care

Outcome: I Non-adherence to final clinic appointment

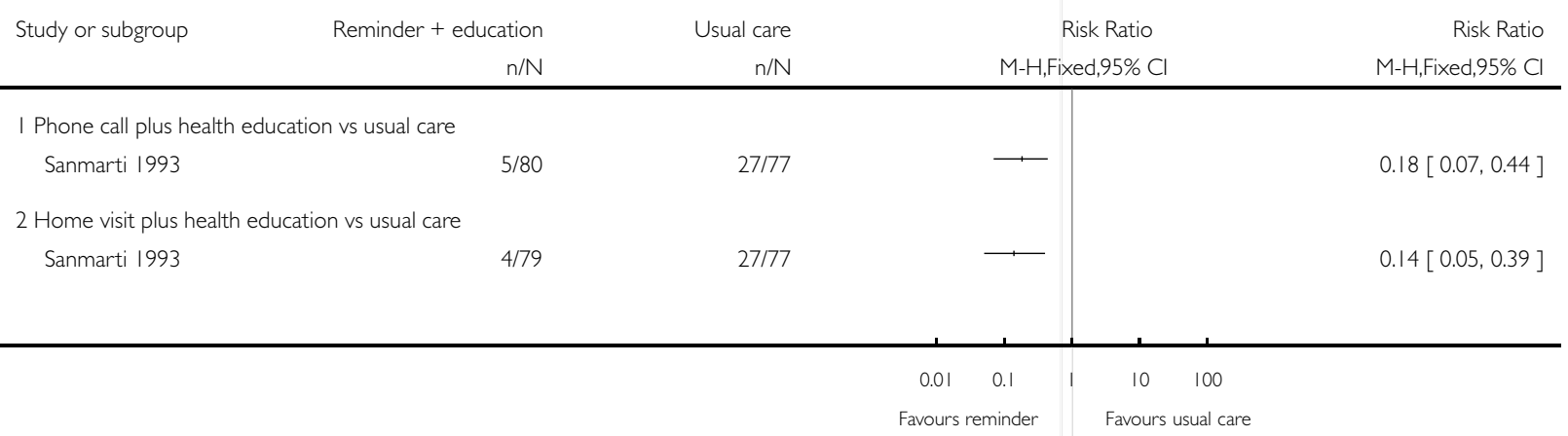


Analysis 7.I. Comparison 7 Reminder vs other types of reminders and no reminder, Outcome I Failed to return for skin test reading.

Review: Reminder systems and late patient tracers in the diagnosis and management of tuberculosis

Comparison: 7 Reminder vs other types of reminders and no reminder

Outcome: I Failed to return for skin test reading

\begin{tabular}{|c|c|c|c|c|}
\hline Study or subgroup & $\begin{array}{r}\text { Reminder } \\
\mathrm{n} / \mathrm{N} \\
\end{array}$ & $\begin{array}{r}\text { Other reminder } \\
\mathrm{n} / \mathrm{N}\end{array}$ & $\begin{array}{c}\text { Risk Ratio } \\
\text { M-H,Fixed,95\% Cl }\end{array}$ & $\begin{array}{r}\text { Risk Ratio } \\
\text { M-H,Fixed,95\% C } \\
\end{array}$ \\
\hline \multicolumn{5}{|c|}{ I Expert vs non-expert } \\
\hline \multicolumn{4}{|c|}{2 Take-home card vs postcard } & $1.20[0.64,2.25]$ \\
\hline \multicolumn{4}{|c|}{3 Take-home card vs telephone call } & $0.94[0.43,2.09]$ \\
\hline $\begin{array}{l}\text { Roberts 1983i } \\
4 \text { Take-home card v }\end{array}$ & $\begin{array}{l}8 / 45 \\
\text { rson }\end{array}$ & $5 / 42$ & & $1.49[0.53,4.20]$ \\
\hline 5 Postcard vs telephone call & $8 / 45$ & $5 / 44$ & & $1.56[0.55,4.41]$ \\
\hline Roberts 1983i & $13 / 69$ & $5 / 42$ & & $1.58[0.61,4.12]$ \\
\hline \multicolumn{5}{|c|}{6 Postcard vs person-to-person } \\
\hline Roberts $1983 i$ & $13 / 69$ & $5 / 44$ & 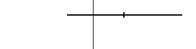 & $1.66[0.64,4.33]$ \\
\hline \multicolumn{5}{|c|}{7 Telephone call vs person-to-person } \\
\hline Roberts $1983 i$ & $5 / 42$ & $5 / 44$ & 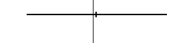 & $1.05[0.33,3.36]$ \\
\hline
\end{tabular}

Analysis 7.2. Comparison 7 Reminder vs other types of reminders and no reminder, Outcome 2 Failed to return for skin test reading.

Review: Reminder systems and late patient tracers in the diagnosis and management of tuberculosis

Comparison: 7 Reminder vs other types of reminders and no reminder

Outcome: 2 Failed to return for skin test reading

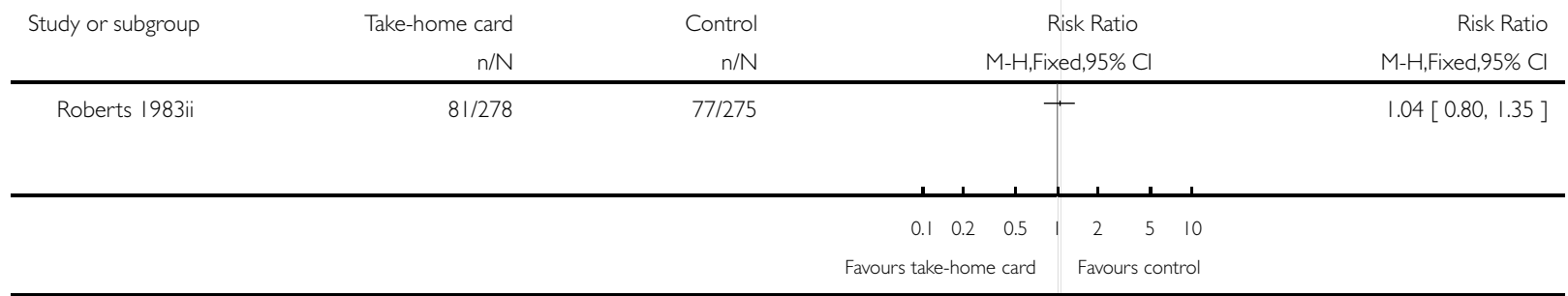




\section{H I S T O R Y}

Protocol first published: Issue 3, 2007

Review first published: Issue 4, 2008

\section{CONTRIBUTIONSOFAUTHORS}

This review was designed in collaboration with all six authors. K Abba and MA Lansang screened the search results; K Abba retrieved the full papers which met the inclusion criteria. K Abba and V Balanag assessed the eligibility of the retrieved papers, and Q Liu acted as third author for this stage. M Alejandria, R Berba, Q Liu, and V Balanag assessed the risk of bias of the included trials and extracted the data from papers; MA Lansang and K Abba acted as third authors. M Alejandria and Q Liu wrote to authors of papers for additional information. Q Liu entered the data into Review Manager 5, undertook the analysis, and interpreted the data in consultation with the other authors. Q Liu drafted the review, and the other authors provided comments and helped to revise the review.

\section{DECLARATIONS OF INTEREST}

None known.

\section{SOURCES OF SUPPORT}

\section{Internal sources}

- No sources of support supplied

\section{External sources}

- Department for International Development (DFID), UK.

\section{DIFFERENCES BETWEEN PROTOCOLAND REVIEW}

We included 'protection against contamination (co-intervention)' as a new criterion for assessing risk of bias because, when not fulfilled, it could result in bias.

\section{NDEX TERMS}

\section{Medical Subject Headings (MeSH)}

${ }^{*}$ Reminder Systems; Patient Compliance; Randomized Controlled Trials as Topic; Tuberculosis, Pulmonary [ ${ }^{*}$ diagnosis; drug therapy] 


\section{MeSH check words}

Adult; Child; Humans 